\title{
The human La (SS-B) autoantigen interacts with DDX15/hPrp43, a putative DEAH-box RNA helicase
}

\author{
MICHAEL A. FOURAUX, ${ }^{1}$ MARLOES J.M. KOLKMAN, ${ }^{1}$ ANNEMARIE VAN DER HEIJDEN, ${ }^{1}$ \\ ARJAN S. DE JONG, ${ }^{2}$ WALTHER J. VAN VENROOIJ, ${ }^{1}$ and GER J.M. PRUIJN ${ }^{1}$ \\ ${ }^{1}$ Department of Biochemistry, Nijmegen Center for Molecular Life Sciences, University of Nijmegen, \\ Nijmegen, The Netherlands \\ ${ }^{2}$ Department of Medical Microbiology, Nijmegen Center for Molecular Life Sciences, University of Nijmegen, \\ Nijmegen, The Netherlands
}

\begin{abstract}
The human La (SS-B) autoantigen is an abundantly expressed putative RNA chaperone, functioning in various intracellular processes involving RNA. To further explore the molecular mechanisms by which La functions in these processes, we performed large-scale immunoprecipitations of La from HeLa S100 extracts using the anti-La monoclonal antibody SW5. La-associated proteins were subsequently identified by sequence analysis. This approach allowed the identification of DDX15 as a protein interacting with La. DDX15, the human ortholog of yeast Prp43, is a member of the superfamily of DEAH-box RNA helicases that appeared to interact with La both in vivo and in vitro. The region needed for the interaction with La partly overlaps the DEAH-box domain of DDX15. Immunofluorescence data indicated that endogenous DDX15 accumulates in U snRNP containing nuclear speckles in HEp-2 cells. Surprisingly DDX15 also accumulates in the nucleoli of HEp-2 cells. Moreover, DDX15 and La seem to colocalize in the nucleoli. Regions of DDX15 involved in nuclear, nuclear speckle, and nucleolar localization are located within the N- and C-terminal regions flanking the DEAH-box. RNA coprecipitation experiments indicated that DDX15 is associated with spliceosomal U small nuclear RNAs in HeLa cell extracts. The possible functional implications of the interaction between La and DDX15 are discussed.
\end{abstract}

Keywords: pre-mRNA splicing; protein-protein interaction; RNA-binding protein; RNA chaperone; small nuclear RNA

\section{INTRODUCTION}

Nuclear pre-messenger RNA (mRNA) splicing is a process used by eukaryotic cells to remove noncoding introns from mRNA precursors. A massive ribonucleoprotein complex called the spliceosome catalyzes the splicing reaction (Moore et al., 1993). Five small nuclear RNAs (snRNAs), U1, U2, U4, U5, and U6, and more than 50 protein factors form the spliceosome (for recent reviews, see Will \& Lührmann, 1997; Staley \& Guthrie, 1998). Although the RNA components of the spliceosome are thought to form the catalytic core, the protein components direct RNA structural rearrange-

Reprint requests to: Ger J.M. Pruijn, Department of Biochemistry 161, University of Nijmegen, P.O. Box 9101, NL-6500 HB Nijmegen, The Netherlands; e-mail: G.Pruijn@ncmls.kun.nl.

Abbreviations: 2D-IEF/SDS-PAGE, two-dimensional-isoelectric focusing SDS-polyacrylamide gel electrophoresis; DBP1, DEAH-box protein 1; mAb, monoclonal antibody; NLS, nuclear localization signal; Pol, RNA polymerase; snRNA, small nuclear RNA; snRNP, small nuclear ribonucleoprotein. ments in the spliceosome that are critical for catalysis (Staley \& Guthrie, 1998). Among these factors are a group of spliceosomal proteins that contain DExD/Hbox RNA helicase domains (Prp2, Prp5, Prp16, Prp22, Prp28, and Prp43) and that were originally identified in the yeast Saccharomyces cerevisiae. These proteins play an essential role at various stages of the splicing reaction (for reviews, see Staley \& Guthrie, 1998; Tanner \& Linder, 2001). Of particular interest for the present study is the Prp43 protein, acting late in the splicing process at the step of spliceosome disassembly (Arenas \& Abelson, 1997; Martin et al., 2002). The mammalian orthologs of Prp43, namely mDEAH9 (murine) and DBP1 (human) have been characterized previously (Gee et al., 1997; Imamura et al., 1997). Whereas mDEAH9 was shown to functionally complement Prp43 in yeast, data on the human protein are still scarce.

The human La (SS-B) protein is an RNA-binding phosphoprotein of $47 \mathrm{kDa}$, originally identified as an autoantigen in patients suffering from autoimmune diseases 
like Sjögren's syndrome and systemic lupus erythematosus (Van Venrooij et al., 1993; Pruijn, 1994). The La protein is ubiquitously expressed in many eukaryotic organisms including S. cerevisiae, Drosophila melanogaster, and Xenopus laevis (Scherly et al., 1993; Bai et al., 1994; Yoo \& Wolin, 1994). Experiments performed in vitro have implicated $\mathrm{La}$ in a variety of cellular processes, for example, RNA polymerase (Pol) III transcription and transcript processing (Gottlieb \& Steitz, 1989a, 1989b; Maraia, 1996) and internal initiation of translation of poliovirus and hepatitis $C$ virus RNA (Meerovitch et al., 1993; Ali \& Siddiqui, 1997; Ali et al., 2000). In a process potentially related to these functions, La has been shown to be capable of unwinding DNA-RNA hybrids and double-stranded RNA in an ATPdependent manner (Bachmann et al., 1990; Xiao et al., 1994; Huhn et al., 1997), although recently the doublestranded RNA-unwinding activity of La has been questioned (James et al., 1999). A role for La in processing of Pol III transcripts has been demonstrated for transfer RNA (tRNA) (Van Horn et al., 1997; Yoo \& Wolin, 1997; Fan et al., 1998). Despite the large body of evidence obtained for the various processes in which La plays a role, the in vivo relevance of these activities of $L a$ is still unknown. The most extensively documented activity of $\mathrm{La}$ is its binding to and stabilization of newly synthesized Pol III transcripts. These transcripts are the precursors to, among others, transfer RNAs, 5S rRNA, 7S rRNAs, U6 RNA, and the Y RNAs (Hendrick et al., 1981; Rinke \& Steitz, 1982, 1985; Fan et al., 1998; Pannone et al., 1998; Kufel et al., 2000). Recently, yeast La has been shown to be involved in $U$ small nuclear ribonucleoprotein (snRNP) assembly and to bind to precursors of U1, U2, U4, U5, and U6 snRNA (Pannone et al., 1998; Xue et al., 2000). Furthermore, La has been shown to associate with the human telomerase ribonucleoprotein complex and its expression level influences telomere homeostasis in vivo (Ford et al., 2001). In addition, certain viral RNAs, such as adenovirus VA RNAs and the leader RNA of vesicular stomatitis virus have been shown to associate with La (Francoeur \& Mathews, 1982; Kurilla \& Keene, 1983). The common binding site for the La protein on these RNAs is the sequence UUU-OH, which is present at the $3^{\prime}$ end of all newly synthesized RNA Pol III transcripts (Stefano, 1984). In most cases, except for the mammalian Y RNAs, the Euplotes telomerase RNA (Aigner et al., 2000), and the virally encoded VA RNAs, this association is transient due to the removal of the 3'-oligouridine stretch during maturation of these RNAs. Recently, La has been proposed to act as an RNA chaperone, which might be consistent with all of its reported activities (reviewed in Maraia \& Intine, 2001).

Human La normally resides in the nucleoplasm, although nucleolar and cytoplasmic localization has also been documented (reviewed in Pruijn et al., 1997). In agreement with its nuclear localization, La contains a nuclear localization signal (NLS) at the $\mathrm{C}$ terminus, and a region responsible for nuclear retention (Simons et al., 1996). The mechanism(s) underlying the subcellular distribution of La has not been determined, although phosphorylation does not seem to play a role (Broekhuis et al., 2000).

To further explore the cellular function(s) of human La, we have used the mouse anti-La monoclonal antibody (mAb) SW5, recognizing a conformational epitope in the RNP motif of La (Pruijn et al., 1995). Large-scale immunoprecipitations of La from HeLa S100 extracts using mAb SW5, followed by sequencing of the coprecipitated proteins, allowed the identification of a 92kDa polypeptide specifically coprecipitated with La. This protein, previously described as DBP1 (Imamura et al., 1997), but renamed DDX15, associates with La both in vivo and in vitro. The possible functional implications of the interaction between La and DDX15 are discussed.

\section{RESULTS}

\section{DDX15 is coprecipitated with La from a HeLa S100 extract}

To identify proteins that either directly or indirectly interact with $\mathrm{La}$, we performed preparative immunoprecipitations from HeLa S100 extracts with the anti-La mAb SW5. SW5 has been shown to be able to precipitate the majority of La-associated RNAs (e.g., the hY RNAs) from HeLa extracts (Pruijn et al., 1995), and thus is likely suited for immunoaffinity selections of La-associated proteins as well. Coprecipitated proteins were eluted by raising the salt concentration to $1 \mathrm{M} \mathrm{NaCl}$ and were fractionated by SDS-PAGE. Because our goal was to identify novel La-associated proteins, we searched for bands in the anti-La precipitate that were absent in the control precipitate (rabbit anti-mouse $\lg G$ ). The efficient coprecipitation of Ro60, a protein that together with $\mathrm{La}$ is a core protein of the Ro ribonucleoprotein complexes (Pruijn et al., 1997), indicated that La-containing macromolecular complexes were selected by this approach (Fig. 1). As can be seen in Figure 1, lane 3, in addition to Ro60 many polypeptides were isolated by this approach using the anti-La mAb. Several bands were chosen for further characterization, and the characterization of the polypeptide indicated with p92, clearly detectable in the anti-La precipitate and absent in the control precipitate (Fig. 1, lanes 2 and 3), will be described in this article. The characterization of several other polypeptides will be reported elsewhere (Fouraux et al., 2002a, 2002b). To determine the identity of p92, we excised the band from the gel, subjected it to trypsin digestion, and analyzed the resulting peptides by mass spectrometry. The peptide masses obtained for p92 by MALDI-TOF mass spectrometry 


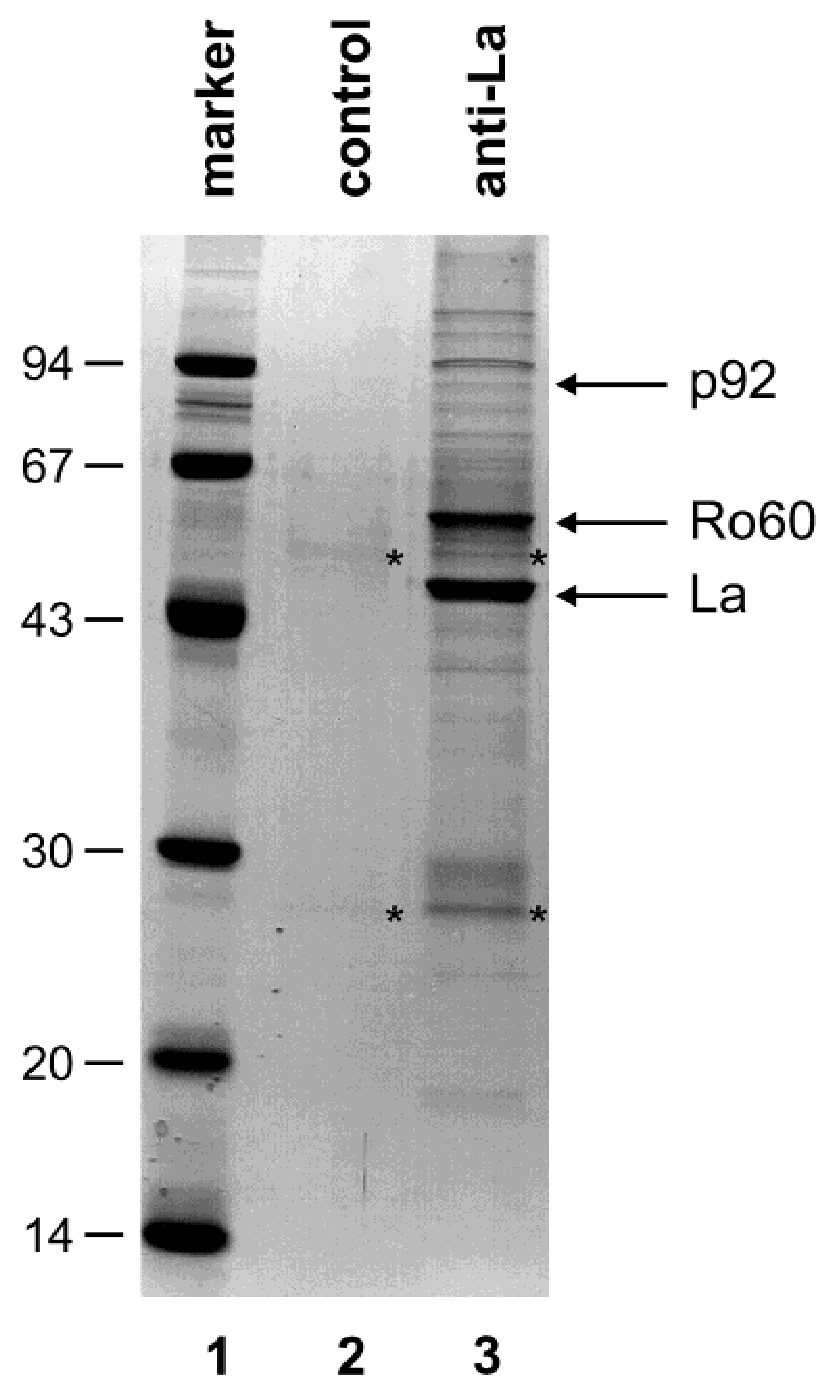

FIGURE 1. Monoclonal antibody SW5 coprecipitates a 92-kDa protein. Protein A-agarose beads coated with anti-La mAb SW5 (antiLa) via rabbit anti-mouse IgG antibodies, or coated with rabbit anti-mouse IgG alone (control), were incubated with a HeLa S100 extract and coprecipitated material was eluted in the presence of $1 \mathrm{M}$ $\mathrm{NaCl}$ and analyzed by SDS-PAGE (12\% acrylamide). The more efficient elution of Ro60 than La from the anti-La resin was expected by this elution method, as antibody-antigen and antibody-Protein A interactions are not efficiently disrupted by $1 \mathrm{M} \mathrm{NaCl}$. Nevertheless, some of the antibody polypeptide chains were observed in the eluates. Proteins were visualized by Coomassie Brilliant Blue staining. Lane 1: molecular weight markers (in kilodaltons); lane 2: control precipitation (rabbit anti-mouse IgG); lane 3: SW5 immunoprecipitation. Arrows indicate the positions of Ro60, La, and p92 and asterisks mark immunoglobulin heavy and light chains. matched with the predicted masses of human DEAHbox protein 1 (DBP1; Imamura et al., 1997; data not shown). The identity was confirmed by the results of tandem Q-TOF mass spectrometry that resulted in five peptide sequences identical to tryptic peptides of DBP1 (see Fig. 2). However, an additional peptide sequence contained an isoleucine residue at a position corresponding to amino acid 149 of DBP1 rather than a glycine residue (DBP1: GenBank accession number AB001636). No additional proteins were identified in this sample. Subsequent cloning and sequencing of p92 cDNAs from two independent human cDNA libraries (placenta and teratocarinoma) demonstrated that these cDNAs, which were identical in both libraries, contained a number of differences compared to the nonredundant database entry of DBP1 (accession number AB001636). At the amino acid level, these differences resulted in several substitutions as well as a frameshift in the C-terminal part of DBP1. The sequence of the cDNAs isolated from the human libraries has been deposited under accession number AF279891 (GenBank). The protein encoded by this sequence was designated DDX15, for DEAH-box protein 15 for reasons documented below. Importantly, the sequence of the sixth peptide, one residue of which did not match the DBP1 sequence, was identical to the corresponding region of DDX15. Like DBP1, DDX15 contains the seven distinct and highly conserved motifs characteristic of the superfamily of DEAH-box putative RNA helicases (see Figs. 2 and 4A; Gorbalenya et al., 1989). In addition, extensive homology was observed between the C-terminal region (amino acids 475 to 767 ) of DDX15 and the yeast members of the DEAH-box RNA helicase family, Prp2, Prp16, Prp22, and Prp43. As noted before for DBP1, DDX15 displays a high degree of homology to the mouse DEAH9 protein, the yeast Prp43 protein, and an uncharacterized Caenorhabditis elegans protein. In contrast, the $\mathrm{N}$-terminal region of DDX15 (amino acids 1 to 160; see Fig. 4A) does not contain significant homology to other known DEAHbox RNA helicases. An extensive region of alternating positively and negatively charged residues (Arg/ Lys-Asp/Glu) is located between amino acids 25 and 60 in the N-terminal part of DDX15.

FIGURE 2. Protein sequence alignment of DDX15 and orthologs from mouse, yeast, and C. elegans. The CLUSTAL W algorithm (Thompson et al., 1994) was used to create an amino acid sequence alignment of DDX15 and the corresponding orthologs mDEAH9 from mouse (Gee et al., 1997), Prp43 from yeast (S. cerevisiae; Arenas \& Abelson, 1997), and C. elegans. The GenBank accession numbers for the corresponding cDNA sequences are: AF279891 (DDX15), AF017153 (mDEAH9), AF005090 (Prp43), and U13644 (C. elegans). Black shading marks the most highly conserved amino acids. Gray shading marks conservation of similar amino acids. The tryptic peptides obtained by the tandem Q-TOF mass spectrometry analysis are depicted above the aligned sequences. Asterisks below the alignment indicate the positions of the motifs characteristic of the superfamily of DEAH-box RNA helicases (Gorbalenya et al., 1989). 
DDX15/human mDEAH $9 /$ mouse Prp43/yeast C.elegans

DDX15/human mDEAH $9 /$ mouse Prp43/yeast C.elegans

LDLGEDYPSGK

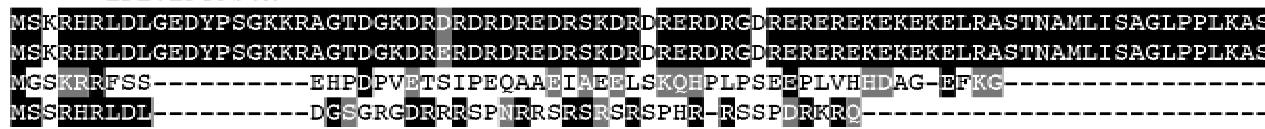

FTDILVR

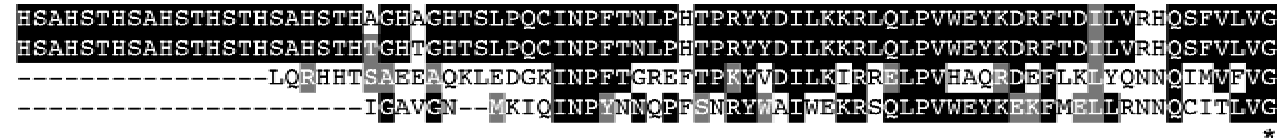

DDX15/human mDEAH $9 /$ mouse Prp43/yeast C.elegans

161

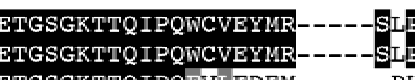

GPKRGVACTQPRRVAAMSVAQRVADEMDVMLGQEVGYSIRFEDCSSAKTILKY PGPKRGVACTQPRRVAAMSVAQRVADEMDVMLGQEVGYSIRFEDCSSAKTILKY 117 ETGSGKTTOIPQFVLFDEM------PHLENTOVACTOPRRVAAMSVAQRVA EMDVKLGEEVGYSIRFENKTSNKTILKY ETGSGKTTQIPQWAVEFMKOQQQGQPPGOARL $\star \star \star \star * \star * \star * \star * *$ ACTQPRRVAAIS

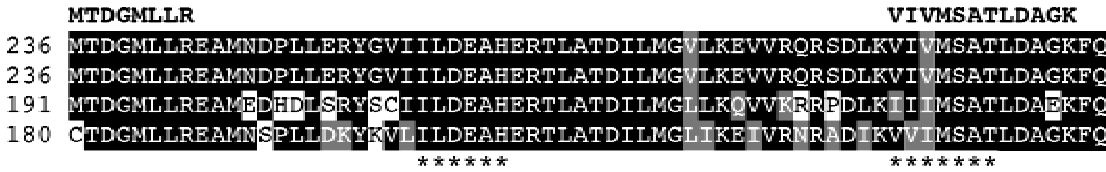

DDX15/human mDEAH9/mouse Prp43/yeast C.elegans

236 236

DDX15/human mDEAH 9 /mouse Prp43/yeast C.elegans

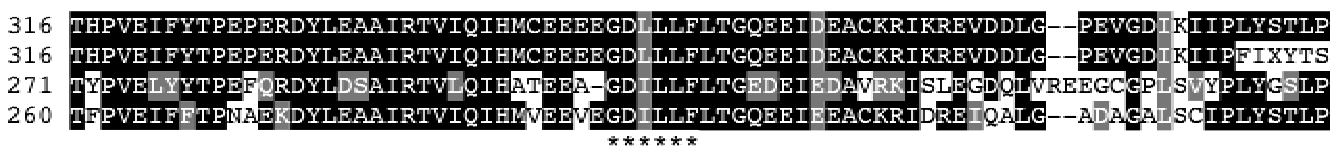

DDX15/human mDEAH $9 /$ mous Prp43/yeast C.elegans
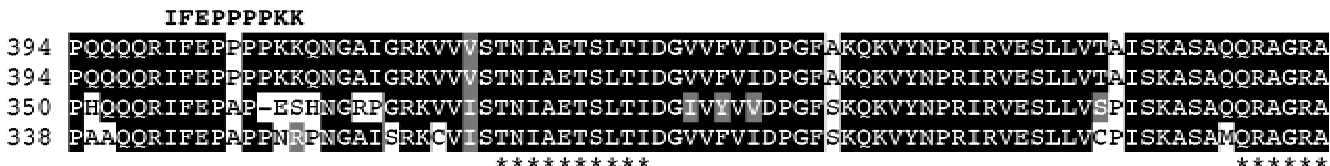

$* * * * * * * * * *$

KTEMODNTYPEILR

DDX15/human mDEAH 9 /mouse Prp43/yeast C.elegans

\section{GRTRPGKCFRLYTEKAYTTPOTYPETIRS} RTRPGKCFRIYTEKAYKTEMODNTYPEILRSNLGSVVLOLKKLGIDDLVHFDFMDPPAPETLMRALELLNYLAALNDDC 429 GRTRPGKCFRLYTEEAFOKEI IEOSYPEILRSNLSSTVLFLKKLGIDDLVHFDFNDPPAPET UMRALEELNYLACLDDEC 418 GRTRPGKCFRLYTETAYGSENODOTYPEILRSNLGSVVLOLKKLGTEDLVHFDFNDPPAPETLMRALELLNYLOATNDDG

DDX15/human mDEAH9/mouse Prp43/yeast C.elegans

554 554 DLTELGSMMAEPLDPQLAKMV IASCDYNCSNEVLSITAMLSVPOCFVRPTEAKKAADEAKMRFAHIDGDHLTLLNVYH 509 ATPLGRL ASOFPLDPMLAVML I SSFIEOCSOEILTIVAMLSVPNVFIRPTKDKKRADDAKNIFAHPDGDHITLLNVYHz 498 ELTELGSLMAEP PLDPLAKMITSTELNCSNEILSITAMLSVPQC NVRPNEMRTEADEAKARFAHIDGDHLTLLNVYHS

DDX15/human mDEAH $9 /$ mouse Prp43/yeast C. elegans

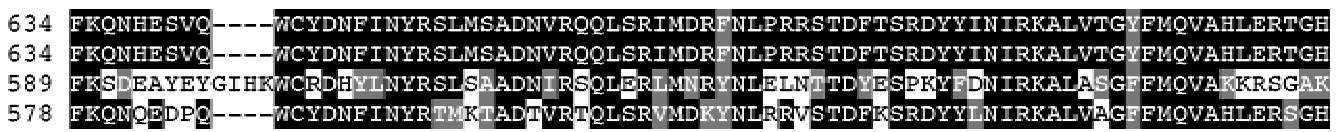

DDX15/human mDEAH $9 /$ mouse Prp43/yeast C.elegans

710 710 YLTVKDNQVVQLHPSTVLDHKPEWVLYNEFVLTTKNYIR 669 GYITVKDNODVIIHPSTVLGHDAEWVIYNEFVLTSKNYIRT 654 -YVTVKDNQLVNLHPSTVLDHKPEWALYNEFVLTTKNF IRTV

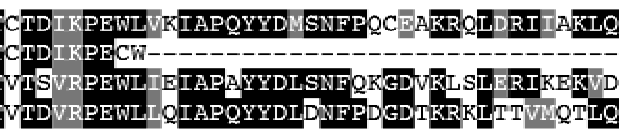

DDX15/human mDEAH $9 /$ mouse Prp4 3/yeast

789 SKEYSOY-

C.elegans

749 RLNELKQGKNKKKSKHSKK

733 RNAGRGY---------

FIGURE 2. See caption on facing page. 
To confirm the association of DDX15 with Lacontaining complexes, we used a rabbit antiserum raised against a synthetic peptide derived from human Prp43/ DDX15. Figure 3A shows that this antiserum, in con-
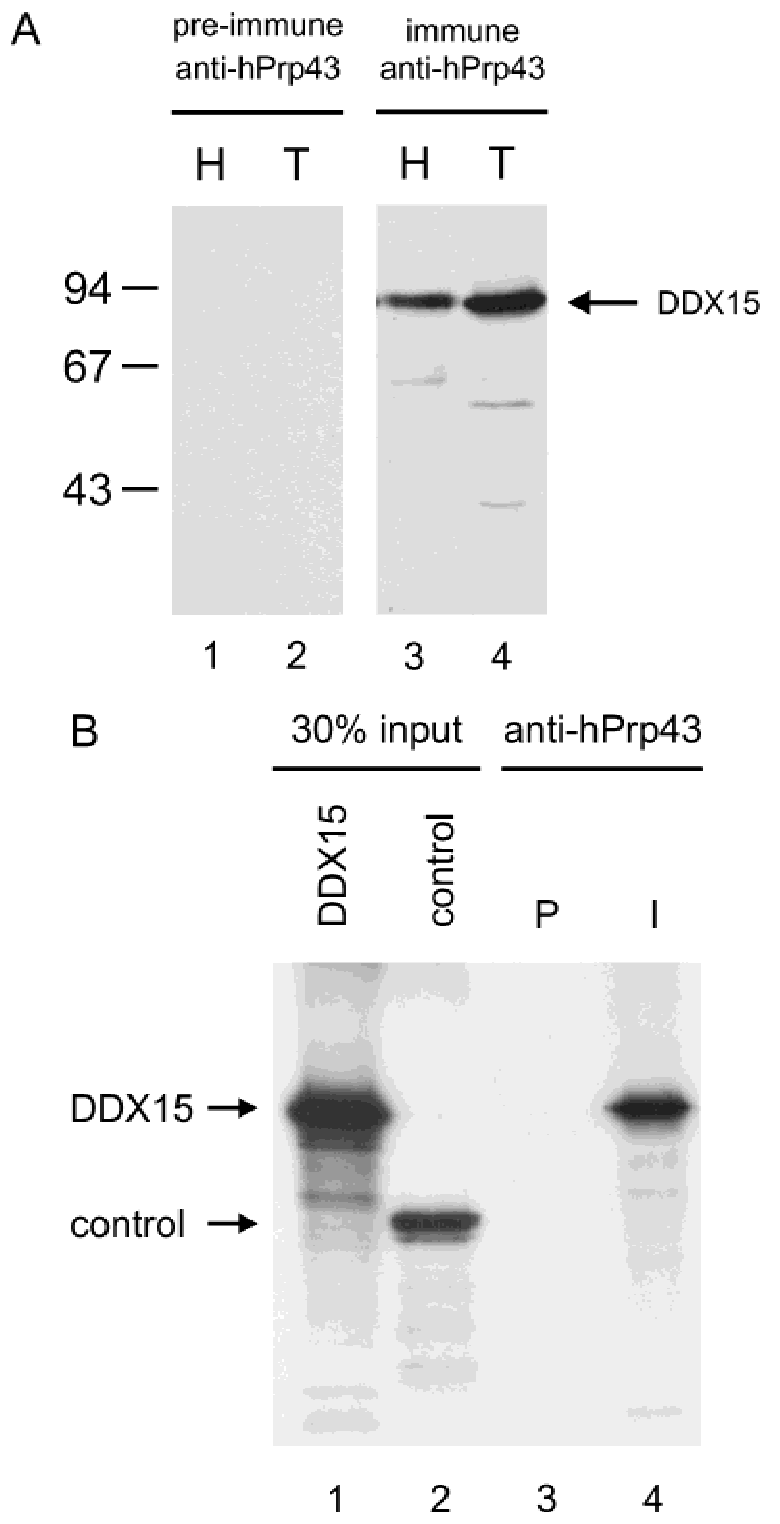

FIGURE 3. The anti-hPrp43/DDX15 serum is reactive with DDX15 both in immunoblotting and immunoprecipitation. A: The reactivity of the rabbit anti-hPrp43/DDX15 serum was analyzed on immunoblots containing both a total HeLa cell extract $\left(2 \times 10^{5}\right.$ HeLa cell equivalents per lane; $\mathrm{H}$ : lanes 1 and 3 ) and in vitro-translated recombinant DDX15 protein (T: lanes 2 and 4). Lanes 1 and 2: preimmune antihPrp43/DDX15 serum; lanes 3 and 4: immune anti-hPrp43/DDX15 serum. The positions of molecular mass markers are indicated on the left (in kilodaltons). B: Protein A-agarose beads coated with antibodies from the preimmune serum $(P)$ or the immune anti-hPrp43/ DDX15 serum (I) were incubated with a (1:1) mixture of in vitrotranslated ${ }^{35}$ S-labeled DDX15 and in vitro translated ${ }^{35}$ S-labeled hnRNP I (which was used as a control). Precipitated proteins were analyzed by gel electrophoresis and autoradiography. Lane 1: $30 \%$ input of ${ }^{35}$ S-labeled DDX15; lane 2: $30 \%$ input of ${ }^{35}$ S-labeled hnRNP I; lane 3: precipitate of preimmune antibodies; lane 4: precipitate of anti-hPrp43/DDX15 antibodies. trast to the corresponding preimmune serum, is reactive with both the native DDX15 protein in a HeLa cell extract (lane 3) and the in vitro-translated recombinant DDX15 protein (lane 4) in immunoblotting. The antihPrp43/DDX15 serum also specifically and efficiently precipitated in vitro-translated DDX15 in an immunoprecipitation assay, in which DDX15 was mixed with an equal amount of in vitro-translated hnRNP I (Fig. 3B, lane 4). Also in this assay, the corresponding preimmune serum was not reactive (Fig. 3B, lane 3). Western blots containing anti-La immunoprecipitates were probed with the hPrp43/DDX15-specific antiserum. Figure 4 shows that DDX15 was indeed coprecipitated by the anti-La mAb (lane 3), but not by the control anti-Ro60 antibody (lane 2). Because La and DDX15 both contain RNA-binding domains and $\mathrm{La}$ is known to bind to RNA directly (Maraia \& Intine, 2001), it was possible that the association between La and DDX15 was mediated by the binding to a common RNA molecule. To investigate this possibility, the HeLa S100 extracts were treated with micrococcal nuclease prior to the immunoprecipitations, which resulted in efficient degradation of RNA molecules present in the extract, including the Ro RNP-associated hY RNAs, as monitored by northern blot hybridization (data not shown). The micrococcal nuclease treatment did not affect the association between La and DDX15, suggesting that the interaction is direct and not dependent on nucleic acids (Fig. 4, lane 5). It should be noted, however, that we cannot completely rule out the possibility that the interaction between La and DDX15 is mediated by an RNA molecule that is inaccessible for the nuclease. To further substantiate the interaction of La with DDX15, we performed inverse immunoprecipitations using the anti-hPrp43DDX15 antiserum and HeLa S100 extracts.

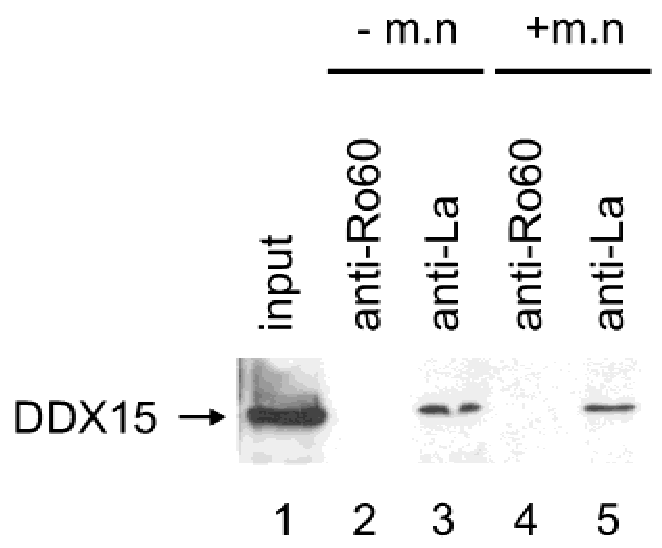

FIGURE 4. DDX15 coprecipitates with La in an RNA-independent manner. Protein A-agarose beads coated with the control anti-Ro60 mAb 2 G10 or the anti-La mAb SW5 were incubated with a HeLa S100 extract preincubated in the absence $(-m . n)$ or presence $(+m . n)$ of micrococcal nuclease. Bound DDX15 was analyzed by immunoblotting using the anti-hPrp43/DDX15 serum. Lane 1: 1\% input; lanes 2 and 4: anti-Ro60 immunoprecipitate; lanes 3 and 5: anti-La immunoprecipitate. 
Western blots containing the anti-hPrp43/DDX15 immunoprecipitates fractionated by two-dimensional isoelectric focusing/SDS-PAGE (2D-IEF/SDS-PAGE) were probed with the anti-La mAb SW5 (Fig. 5). Twodimensional gels were used here to prevent interference by immunoglobulin heavy chains, which are known to comigrate with $\mathrm{La}$ and disturb the interpretation of this experiment. In agreement with the results in Figure 4, La was specifically coimmunoprecipitated with DDX15. Also in this case, micrococcal nuclease treatment of the cell extract prior to immunoprecipitation did not disrupt the association between La and DDX15, corroborating the suggestion that the interaction is direct and not dependent on nucleic acids (data not shown).

\section{La interacts with DDX15 in vitro}

To study the interaction between La and DDX15 in more detail, we used a recombinant GST-La fusion protein and in vitro-translated ${ }^{35} \mathrm{~S}$-methionine-labeled DDX15 protein in a GST pull-down assay. In addition to the GST-La fusion protein (Fig. 6A, lane 3) GST was used as a control (Fig. 6A, lane 2). Incubation of in vitrotranslated wild-type DDX15 with GST-La preabsorbed to immobilized glutathione revealed that DDX15 associated with GST-La (Fig. 6C, lane 10), even under relatively stringent conditions $(300 \mathrm{mM} \mathrm{KCl})$. No binding was observed using the GST-protein alone, indicating that the binding was mediated by the La moiety of the GST-La fusion protein (Fig. 6C, lane 19). The analysis of a panel of deletion mutants of DDX15 (Fig. 6B) in this assay allowed the mapping of the La-binding site on DDX15. The results showed that La interacts with the region between amino acids 153 and 286 on the DDX15 protein, as deletion of this region abolished the association of La and DDX15 completely (Fig. 6C). Deletion of the N-terminal 152 and/or C-terminal parts of DDX15 up to amino acid 477 (mutants $\Delta$ C689, $\Delta$ C583, and $\Delta$ C477) had no effect on the association between La and DDX15 (Fig. 6C). Analysis of the supernatant of the pull-down experiment with $\Delta \mathrm{N} 286$ revealed that the lack of precipitation of this mutant was not caused by degradation during the incubation period (Fig. 6D, lane 14). As additional controls to demonstrate that the precipitation of DDX15 under these conditions is specific, we performed parallel experiments with the in vitro translated hnRNP I and hnRNP K proteins. The results indeed show that under the same experimental conditions, these proteins are not detectably coprecipitated with the GST-tagged La protein (Fig. 6D).

\section{DDX15 accumulates in both nuclear speckles and nucleoli of HEp-2 cells and partially colocalizes with La in nucleoli}

DDX15 and its orthologs have not been extensively studied, unlike several other members of the DEAHbox RNA helicase family (Arenas \& Abelson, 1997; Gee et al., 1997; Imamura et al., 1997). To gain more insight into the subcellular localization of this protein, and to investigate if DDX15 colocalizes with $\mathrm{La}$, which is suggested by the observed interaction between La and DDX15, we visualized DDX15 in HEp-2 cells using the anti-hPrp43/DDX15 specific antiserum. The La protein was visualized using the anti-La mAb SW5 (Pruijn et al., 1995). As shown in Figure 7A, DDX15 was found both in nuclear speckles and in the nucleoli. No detectable staining of the cells was observed with the corresponding preimmune serum (data not shown). In agreement with many previously published data, the anti-La antibody stained the nucleoplasm as well as the nucleoli (Fig. 7B). The overlay of the anti-hPrp43/DDX15 and the anti-La stained cells shows that the most pronounced colocalization of these two proteins occurs in the nucleoli. To shed more light on the identity of the nucleoplasmic speckles stained by anti-hPrp43/DDX15, we performed colocalization experiments with monoclonal antibodies against the Sm-proteins (Figs. 7D-F; Lerner et al., 1981) and the U2 snRNP specific B" protein (Figs. 7G-I), which are known to localize to nuclear speckles that are enriched in splicing factors (Habets et al., 1989). The nucleoplasmic staining patterns (obtained by confocal microscopy) of the anti-hPrp43/ DDX15 antibodies and the anti-Sm and anti-U2B" mAbs were coincident, as indicated by the yellow staining in the merged images (Figs. 7F, I). These results demonstrate that DDX15, the Sm-proteins, and U2B" colocal-

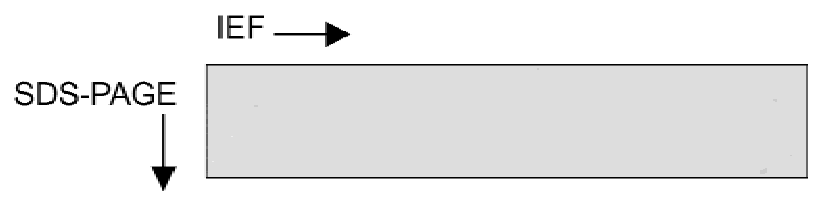

pre-immune anti-hPrp43

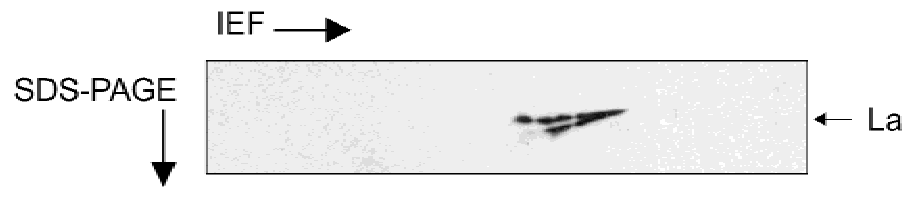

FIGURE 5. La coprecipitates with DDX15. Protein A-agarose beads coated with antibodies from the preimmune serum or from the anti-Prp43/DDX15 serum were incubated with a HeLa cell S100 extract. Coprecipitated proteins were eluted in 2D sample buffer and fractionated by 2D-IEF/SDS-PAGE followed by immunoblotting using the anti-La mAb SW5. The slightly faster migrating spots that are reactive with SW5 correspond to degradation products of the La protein. 


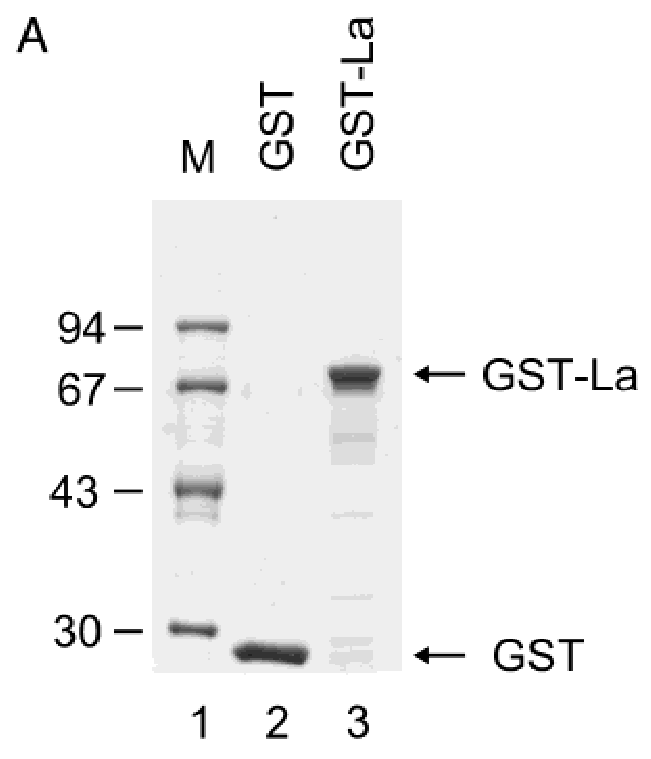

B

DDX15
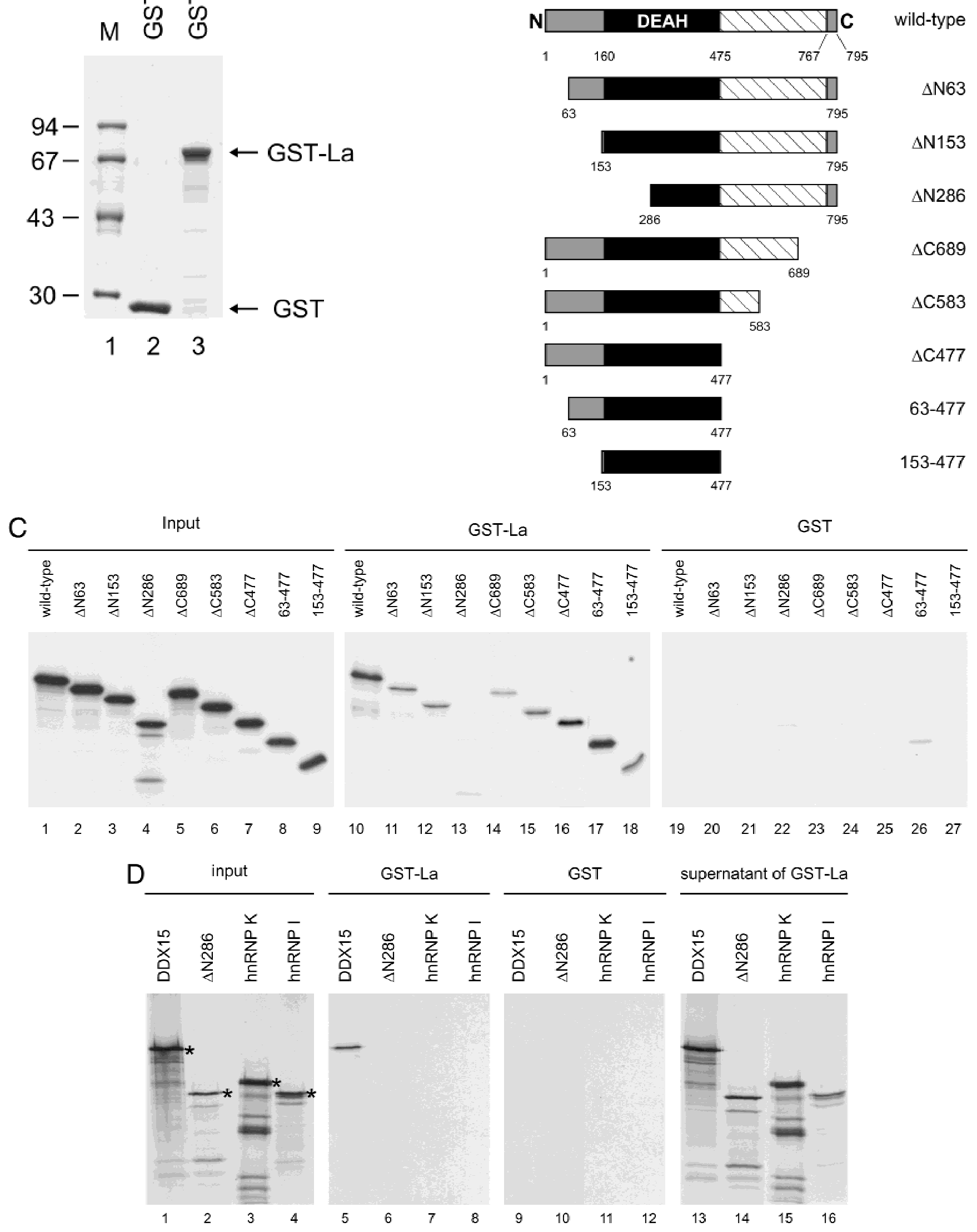

FIGURE 6. See caption on facing page. 
ize in nuclear speckles. As mentioned above, nucleolar staining was also observed with anti-DDX15 antibodies (Fig. 7A). The nucleolar accumulation of DDX15 was confirmed by the colocalization of DDX15 with the nucleolar protein fibrillarin (Aris \& Blobel, 1991; Figs. 7J-L). Taken together, these immunofluorescence data show that DDX15 accumulates in U snRNP containing nuclear speckles as well as in nucleoli of HEp-2 cells.

\section{DDX15 contains multiple localization signals in both the $\mathrm{N}$-terminal and the $\mathrm{C}$-terminal part of the protein}

To further characterize the DDX15 protein, we constructed a series of N-terminally VSV-G-tagged DDX15 mutants and analyzed their subcellular localization by indirect immunofluorescence microscopy using transiently transfected cells expressing these mutants. Immunoblotting analysis of extracts from the transfected cells showed that all DDX15 mutants were expressed to similar levels and that they migrated at positions that were in accordance with their expected molecular masses (data not shown). As shown in Figure 8A, B, the wild-type VSV-G-tagged DDX15 localized to speckles in the nucleoplasm and to nucleoli, as observed for the endogenous DDX15 protein (see Fig. 7). This result shows that the N-terminal VSV-G-tag did not influence the intracellular distribution of DDX15. A deletion mutant of DDX15 lacking the N-terminal 62 amino acids ( $\triangle$ N63) showed a subcellular distribution similar to the wild-type protein (Fig. 8C, D) except for the absence from the nucleoli. This suggests that the region between amino acids 1 and 62 is essential for the nucleolar accumulation of DDX15. A further truncation from the $\mathrm{N}$-terminal side abrogated nuclear entry, because mutant $\Delta \mathrm{N} 153$ localized primarily to the cytoplasm (Fig. 8E, F), suggesting that the region between amino acids 63 and 152 is required for the nuclear localization of DDX15. Interestingly, deletion of C-terminal parts of DDX15, mutants $\Delta$ C689 and $\Delta \mathrm{C} 583$, led to a homogeneous nucleoplasmic dis- tribution with no or hardly any nucleolar staining (Fig. 8G, H, and I, J). The lack of accumulation in nucleoplasmic speckles and nucleoli observed with these mutants suggests that the region between amino acids 690 to 795 is required for targeting DDX15 to nuclear speckles. Nucleolar accumulation of DDX15 apparently depends on two regions of this protein, namely amino acids 1 to 62 and 690 to 795 .

\section{Spliceosomal U snRNAs coprecipitate with DDX15 from a HeLa extract}

Previous studies on DEAH-box proteins (e.g., Prp16, Prp22, and Prp43) in yeast revealed that these proteins are involved in some aspects of RNA metabolism, particularly pre-mRNA splicing (reviewed in De la Cruz et al., 1999). This prompted us to investigate if DDX15 associates with cellular RNAs. DDX15 was immunoprecipitated from HeLa cell extracts using the rabbit antihPrp43/DDX15 serum and coprecipitated RNAs were size-fractionated and visualized by silver staining. Because it is possible that La and DDX15 (in part) associate as a complex with the same RNAs, we also included the anti-La mAb SW5 in these experiments, as well as a monoclonal anti-Sm antibody (Y12) as a control. The results in Figure 9 (lanes 4 and 5) show that the anti-hPrp43/DDX15 antibodies coprecipitated several RNAs. Comparison of the pattern of these RNAs with those coprecipitated by mAb Y12 (Fig. 9, lane 3), which has previously been shown to precipitate $U$ snRNP particles (Lerner et al., 1981), strongly suggested that these represent the $U 1$ and $U 2$ snRNAs. In addition to these RNAs, we also reproducibly observed RNAs migrating at the positions of the U4, U5, and U6 snRNAs, although in Figure 9 these RNAs are not visible. We have, however, confirmed the identity of the putative $U$ snRNAs by northern blot hybridization analysis (not shown). The association of DDX15 with the U snRNAs was not detectable when the immunoprecipitations were performed at $200 \mathrm{mM}$ or higher $\mathrm{NaCl}$ concentrations, indicative of a relatively weak interaction (data not shown).

FIGURE 6. The La-binding site on DDX15 maps to a region between amino acids 153 and 286. A: Purity of recombinant GST-La and GST proteins used in the GST pull-down assay. Samples of GST-La and GST were fractionated by SDS-PAGE, and subsequently the gel was stained using Coomassie Brilliant Blue. Lane 1: molecular weight marker (in kilodaltons); lane 2: GST protein; lane 3: GST-La protein. B: Schematic structure of DDX15 truncation mutants. DDX15-specific regions are in gray, whereas the highly conserved DEAH-box domain is marked in black. The region of DDX15 that corresponds to a region conserved among the yeast DEAH-box proteins Prp2, Prp16, Prp22, and Prp43 is hatched. Numbers below the schematic structures refer to amino acid positions in DDX15. C: Pull-down assay of in vitro-translated DDX15 and deletion mutants of DDX15. Glutathione beads coated with GST-La or GST alone were incubated with in vitro-translated ${ }^{35} \mathrm{~S}$ methionine-labeled DDX15 and mutants thereof, and precipitated proteins were analyzed by gel electrophoresis and autoradiography. Lanes 1-9: 5\% input; lanes 10-18; GST-La pull-down; lanes 19-27: GST pull-down (control). D: Specificity controls for the GST-La pull-down assay. Glutathione beads coated with GST-La or GST alone were incubated with in vitro-translated ${ }^{35} \mathrm{~S}$-methionine-labeled DDX15 (lanes 1, 5, 9, 13), mutant $\Delta \mathrm{N} 286$ (lanes 2, 6, 10, 14), or the hnRNP K (lanes $3,7,11,15)$ and hnRNP I (lanes 4, 8, 12,16) proteins. Precipitated proteins were analyzed by gel electrophoresis and autoradiography. Lanes 1-4: 5\% input (asterisks mark the positions of the full-length proteins); lanes 5-8: GST-La pulldown; lanes 9-12: GST pull-down (control); lanes 13-16: unbound material (5\% of supernatant) from GST-La pull-down incubations. 

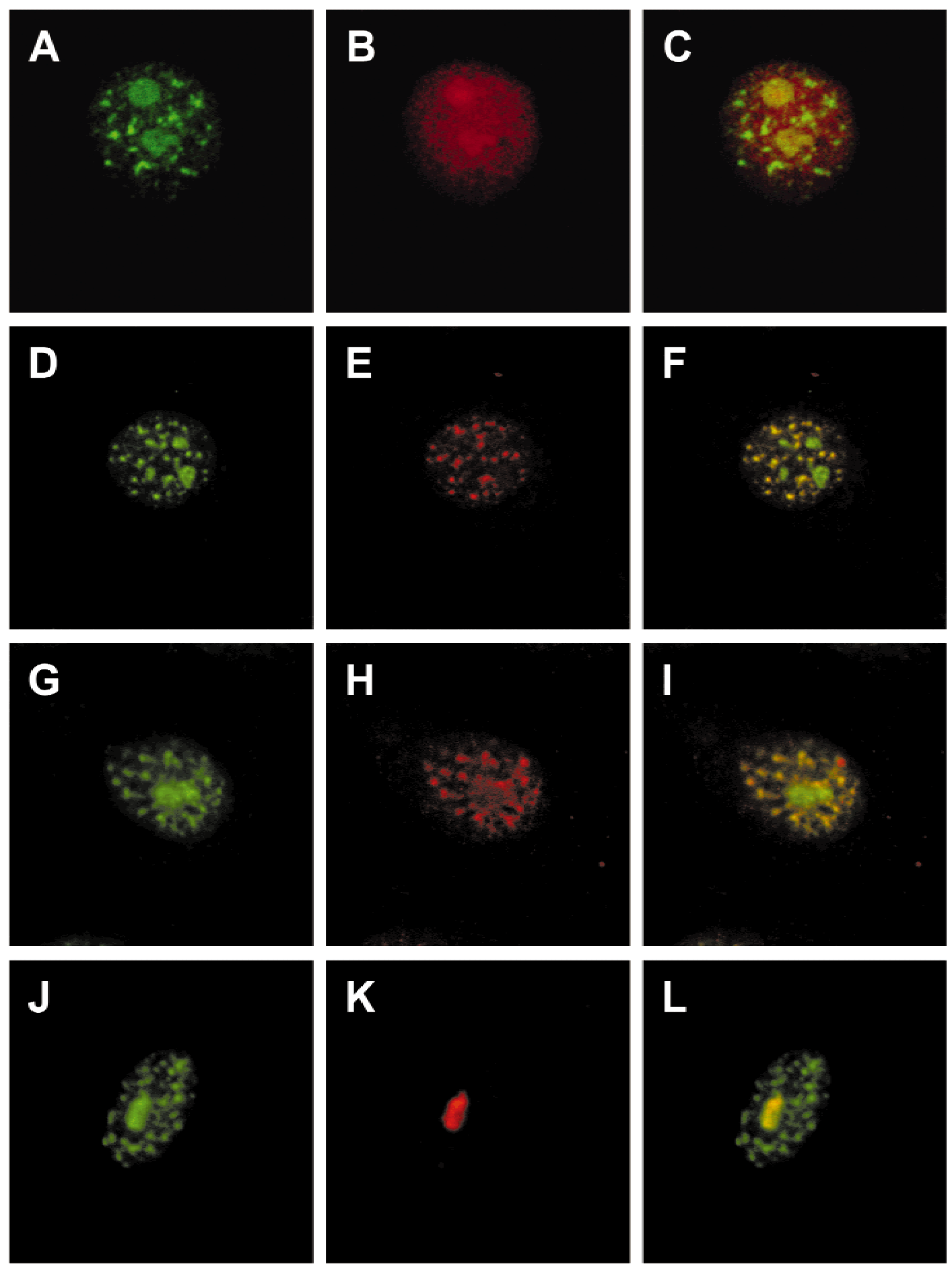

FIGURE 7. DDX15 accumulates in nuclear speckles and nucleoli of HEp-2 cells and partially colocalizes with La in nucleoli. A, D, G, J: HEp-2 cells incubated with the anti-hPrp43/DDX15 antibodies, followed by visualization with FITC-conjugated secondary antibodies and confocal fluorescence microscopy (green). B: HEp-2 cells incubated with mAb SW5 (anti-La) and visualized by Texas Red-conjugated secondary antibodies (red). C: Merged image of A and B, showing a partial colocalization of DDX15 and La in nucleoli (yellow). E: HEp-2 cells incubated with mAb Y12 (anti-Sm) and visualized by Texas Red-conjugated secondary antibodies (red). F: Merged image of D and E, showing colocalization of DDX15 and Smproteins in nuclear speckles (yellow). H: HEp-2 cells incubated with mAb 4G3 (anti-U2B") visualized by Texas Redconjugated secondary antibodies (red). I: Merged image of $\mathbf{G}$ and $\mathbf{H}$, showing colocalization of DDX15 and U2B" in nuclear speckles (yellow). K: HEp-2 cells incubated with mAb 72B9 (anti-fibrillarin) visualized by Texas Red-conjugated secondary antibodies (red). L: Merged image of $\mathbf{J}$ and $\mathbf{K}$, showing colocalization of DDX15 and fibrillarin in nucleoli (yellow). All images were generated by confocal microscopy. 

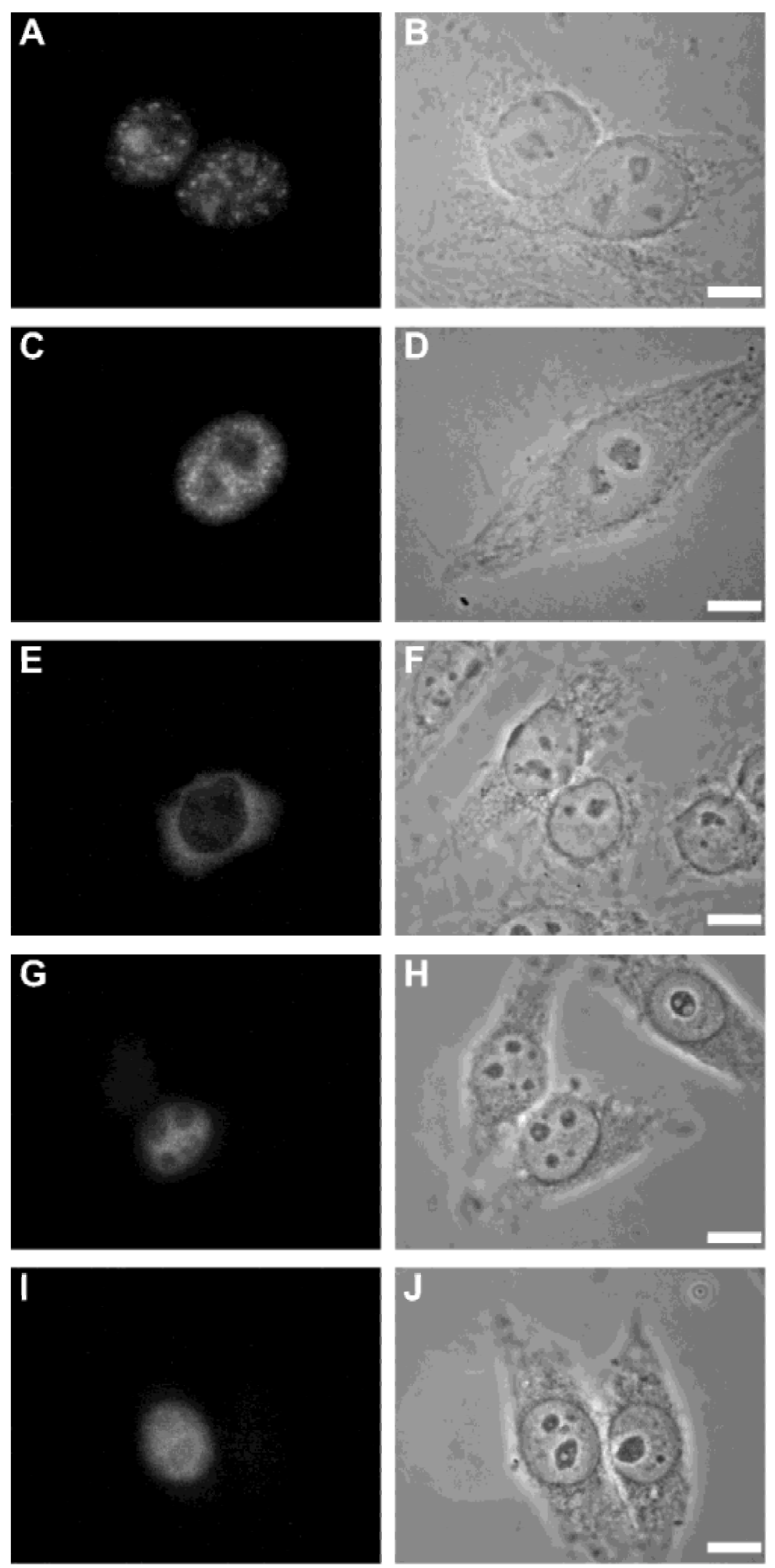

FIGURE 8. Subcellular localization of VSV-Gtagged DDX15 and DDX15-mutants in HEp-2 cells. A-J: HEp-2 cells were transiently transfected with constructs encoding the VSV-G-tagged wild-type $\operatorname{DDX} 15(\mathbf{A}), \Delta \mathrm{N} 63$ (C), $\Delta \mathrm{N} 153$ (E), $\Delta \mathrm{C} 689$ (G), and $\Delta$ C583 (I). Twenty-four hours after transfection, cells were fixed and incubated with a mouse anti-VSVG-tag antibody, which was visualized with a FITCconjugated rabbit anti-mouse antibody. B, D, F, H, $\mathrm{J}$ : corresponding phase-contrast images; bar represents $10 \mu \mathrm{m}$. All images in this figure were generated by epifluorescence microscopy.
Some coprecipitation of the small ribosomal $5.8 \mathrm{~S}$ and $5 \mathrm{~S}$ RNAs was reproducibly observed. Comparison of the RNAs coprecipitated with DDX15 (Fig. 9, lane 5) with those coprecipitated with La (Fig. 9, lane 2) revealed hardly any overlap, although weak signals at the $\mathrm{U} 1, \mathrm{U} 4$, and $U 6$ positions were observed in the La lane. 


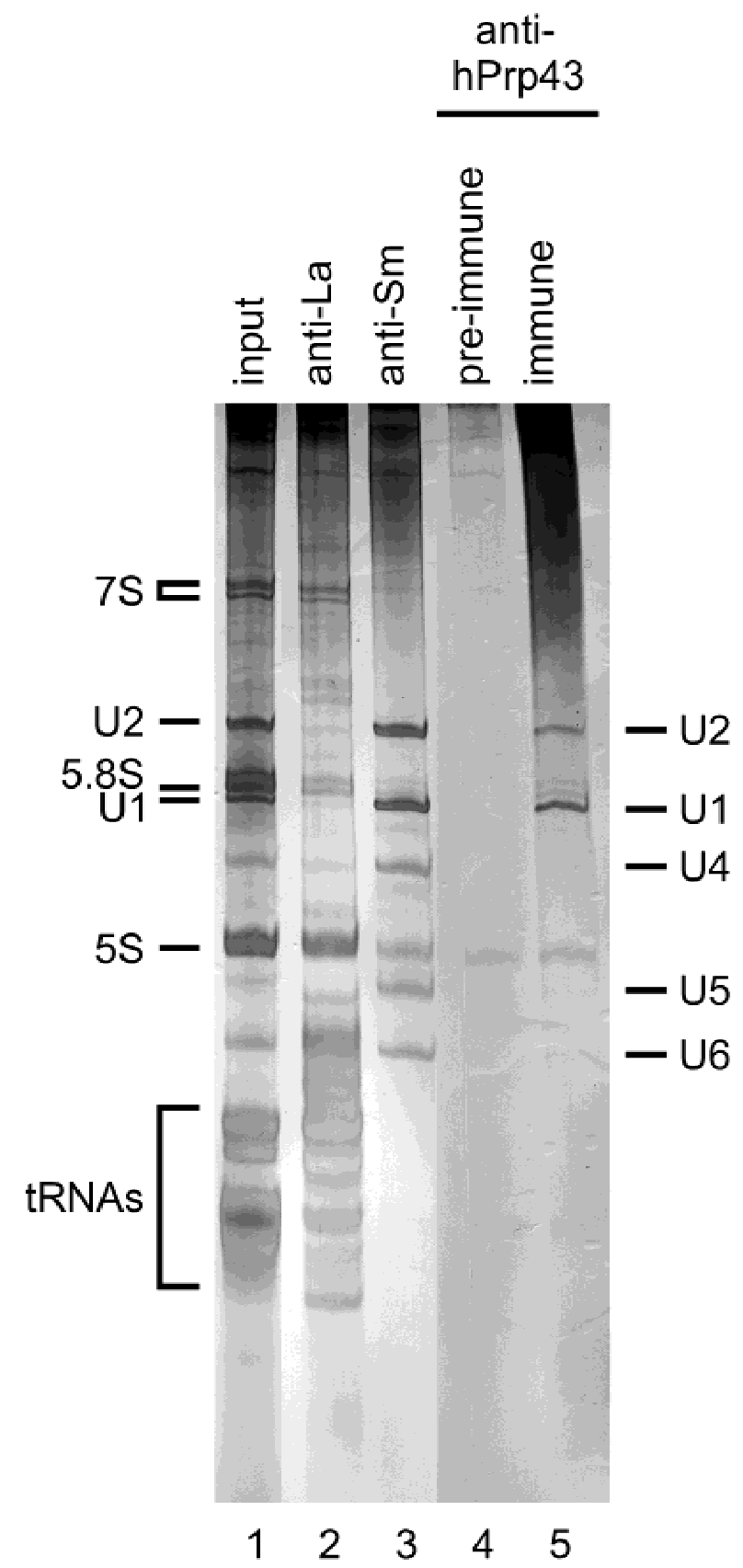

FIGURE 9. Anti-hPrp43/DDX15 antibodies coprecipitate U snRNAs. A HeLa cell extract was subjected to immunoprecipitation using mAbs SW5 (anti-La) and Y12 (anti-Sm), the anti-hPrp43/DDX15 serum (immune), and the corresponding preimmune serum. Coprecipitated RNAs were isolated and analyzed by denaturing polyacrylamide gel electrophoresis and subsequent silver staining. The input lane contains RNAs isolated from the complete cell extract $(10 \%$ of the amount used in the immunoprecipitations). The positions of U1-U6 snRNAs and of the most prominent RNAs in the input lane are indicated. Lane 1: 10\% input RNAs; lane 2: anti-La immunoprecipitation (SW5); lane 3: anti-Sm immunoprecipitation (Y12); lane 4: anti-Prp43/DDX15 preimmune serum immunoprecipitation; lane 5: anti-hPrp43/DDX15 immunoprecipitation.

\section{DISCUSSION}

Using the anti-La mAb SW5 to identify La-interacting proteins, we identified human DDX15, a member of the superfamily of DEAH-box putative RNA helicases (Gorbalenya et al., 1989). Proteins of this superfamily are thought to unwind double-stranded RNA molecules in an energy-dependent fashion through the hydrolysis of NTP (generally ATP). In addition, some DExD/H helicases may be involved in disrupting or rearranging RNA-protein interactions (Jankowsky et al., 2001; Linder et al., 2001). The putative RNA helicases, also called "unwindases", function in a variety of cellular processes involving RNA, including ribosome biogenesis, premRNA editing and splicing, transcription, RNA export, and RNA degradation (for reviews, see Staley \& Guthrie, 1998; De la Cruz et al., 1999; Tanner \& Linder, 2001). The cDNA sequence of DDX15 appeared to be very similar to the previously identified DBP1 cDNA (Imamura et al., 1997). Because only a single cDNA sequence for DDX15 was isolated from two independent cDNA libraries (placenta and teratocarcinoma), the possibility exists that the differences between the DDX15 and DBP1 cDNAs are due to sequencing errors in the database entry for DBP1. This is further supported by the fact that the sequence of all tryptic peptides of this protein isolated from HeLa cells and analyzed by mass spectrometry corresponded to the DDX15 sequence, whereas one peptide did not fully match the DBP1 sequence.

Although our data suggest a direct interaction between La and DDX15 both in vivo and in vitro, we cannot completely exclude the possibility that the observed interaction is mediated by another macromolecule, which may be present in both HeLa cell extracts and reticulocyte lysates.

Previously, a helicase activity has been reported to be associated with immunoaffinity-purified La protein from mouse and calf cell extracts (Bachmann et al., 1990). If we assume that DDX15 indeed can act as an (RNA) helicase, the question is raised whether this can account for the reported La-associated helicase activity. This possibility seems unlikely, however, because the helicase activity was found to be associated with La purified to homogeneity and to be inhibited by anti-La antibodies, thus suggesting that La itself also possesses helicase activity. This was further substantiated by the finding that recombinant, bacterially expressed human $\mathrm{La}$ is able to unwind double-stranded RNA (Huhn et al., 1997).

\section{Specificity of DDX15}

The modular structure of DDX15, consisting of a helicase core (DEAH-box) and the $\mathrm{N}$ - and C-terminal extensions, is common for the family of $\mathrm{DExD} / \mathrm{H}$ proteins (Fig. 8; De la Cruz et al., 1999). It has been proposed that the regions flanking the DexD/H-box domain of $\mathrm{DExD} / \mathrm{H}$-box family members, which are unique for each of these proteins, may determine their specificity (Wang \& Guthrie, 1998; Tanner \& Linder, 2001). For instance, the N-terminal domain of Prp16 is required for its spe- 
cific association with the spliceosome (Wang \& Guthrie, 1998). However, in some cases, the DExD/H-box domain itself may also determine specificity, because eIF4A, a prototype DEAD-box RNA helicase, consists essentially of a helicase core without extensions, but still is a highly specific enzyme (Linder et al., 1989). This hypothesis is strengthened by the fact that the regions responsible for the interactions between the human DEAD-box RNA helicases p68 and hDbp5 with fibrillarin and CAN/Nup159p, respectively, are located within the DEAD-box region of the two proteins (Schmitt et al., 1999; Nicol et al., 2000). Similarly, our in vitro binding studies using GST-La and ${ }^{35}$ S-labeled DDX15 indicate that residues exposed at the surface of the helicase core of DDX15 (between amino acids 153 and 285; Fig. 10) mediate the interaction with La. Determination of the identity of several other proteins coprecipitated with La did not identify other DExD/H-box RNA helicases, strongly suggesting that this interaction is specific for the helicase core of DDX15 (M.A. Fouraux \& G.J.M. Pruijn, unpubl. data). A deletion analysis of $\mathrm{La}$ did not allow the determination of the region bound by DDX15 (all mutations abrogated the interaction), suggesting that various regions of La are important for this interaction (data not shown).

\section{Subcellular localization of DDX15}

The N-terminal and C-terminal extensions of DDX15 seem to play a role in the subcellular localization of DDX15. Using the anti-hPrp43/DDX15 rabbit serum, we showed that endogenous DDX15 localizes to nuclear speckles and, surprisingly, to nucleoli of HEp-2 cells (Fig. 7). The subcellular localization of DDX15 to nuclear speckles and colocalization with the splicing factor U2B" and the Sm-proteins are in agreement with the fact that the yeast ortholog Prp43 has been reported to be involved in spliceosome disassembly (Arenas \& Abelson, 1997). Moreover, recently it was reported

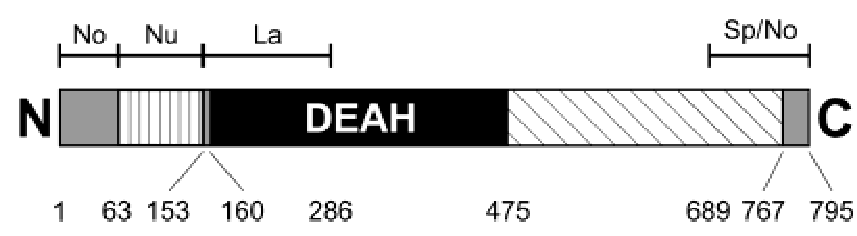

FIGURE 10. Schematic structure of DDX15. DDX15-specific regions are depicted in gray, whereas the highly conserved DEAH-box domain is marked in black (DEAH). The region of DDX15 that corresponds to the region conserved among the yeast DEAH-box proteins Prp16, Prp2, Prp22, and Prp43 is hatched (diagonal hatch). The region required for nuclear localization is indicated by $\mathrm{Nu}$ (vertical hatch); the region bound by La is marked by La and a bar above the scheme. Regions involved in nucleolar localization are indicated by No (bar above scheme), whereas the region involved in the localization of DDX15 to nuclear speckles is indicated by Sp (bar above scheme). Numbers below the structure refer to amino acid positions in DDX15. by Martin et al. (2002) that Prp43 represents an essential RNA-dependent ATPase required for the release of the excised lariat-intron from the spliceosome. The observation that DDX15 also accumulates in nucleoli suggests that, besides functioning in splicing, DDX15 is also involved in other processes (see below). Data from the literature on the localization of DDX15 and its homologs is very limited. The nucleolar accumulation of DDX15 was recently corroborated by the proteomic analysis of purified human nucleoli, in which DDX15 was identified as a nucleolar protein (Andersen et al., 2002). Whereas several DExD-box RNA helicases were identified, no other members of the DExH-box RNA helicase family were identified in this analysis of nucleolar proteins (Andersen et al., 2002). Imamura et al. (1997) reported that a GFP-tagged version of DBP1 localized to the nucleus of HeLa cells. However, they did not observe the nuclear speckles and nucleolar accumulation we report in this article. The mouse ortholog of DDX15, mDEAH9, was shown to localize to nuclear speckles, but was not observed in the nucleoli (Gee et al., 1997). The discrepancies between our results and the results obtained with DBP1 and mDEAH9 might be explained by sequence differences between the three proteins. First, the sequence of DBP1 contains a frameshift, resulting in an alternative $\mathrm{C}$-terminal end in comparison with DDX15; second, whereas the murine and human proteins are almost identical over the whole protein sequence, mDEAH9 does have a shorter C-terminal part compared to DDX15 (see Fig. 2). Based on these observations we suggest that the C-terminal part is important for the subnuclear localization of DDX15. This is corroborated by the results from the deletion analysis of DDX15. In agreement with the nuclear localization of DDX15, we identified a region required for its entry into the nucleus between amino acids 63 and 153 (see Fig. 10). A deletion of amino acids 690 to 795 abolished its association with nuclear speckles, substantiating the importance of this region for its subnuclear localization. Other $\mathrm{DExD} / \mathrm{H}$ family members, like hPrp16 and $\mathrm{HRH} 1$, also have been reported to accumulate in speckles. The localization of hPrp16 and $\mathrm{HRH} 1$ to nuclear speckles is mediated by their RS domains (Ohno \& Shimura, 1996; Ortlepp et al., 1998), which is not discernable in the DDX15 sequence. Detailed analysis of the region spanning amino acids 690 to 795 is therefore needed to identify the amino acids involved in the targeting of DDX15 to nuclear speckles. The nucleolar accumulation of DDX15 appeared to require two, spatially separated regions of the protein (Fig. 10). Deletion of amino acids 1 to 62 in the N-terminal part abolished nucleolar accumulation, whereas the association with nuclear speckles remained unaffected. The sequence of this region is characterized by the presence of a stretch of alternating basic and acidic residues between amino acids 25 and 60 . This repeat can be subdivided into two parts based 
upon the presence of mainly aspartic acids (amino acids 25 to 48) or glutamic acids (amino acids 49 to 60). Arg-Asp repeats have been previously implicated in RNA binding (Staknis \& Reed, 1995) and regions rich in basic residues have been shown to mediate nucleolar accumulation (Van Eenennaam et al., 2001). Further experiments are required to determine whether these charged regions are involved in the nucleolar localization of DDX15. Deletion of amino acids 690 to 795 in the C-terminal part of DDX15 also abolished nucleolar accumulation of DDX15. The lack of nucleolar localization of mDEAH9, the murine homolog of DDX15 (Gee et al., 1997) suggests that amino acids 756 to 795 of DDX15 play a crucial role in its nucleolar localization. In sum, all data on the localization of DDX15 mutants support the notion that $\mathrm{N}$-terminal and C-terminal extensions of DEAH-box proteins confer specificity to these proteins. It should be noted however, that also the DEAH-box domain itself is determining part of the specificity of DDX15, namely the association of La with a part of the DEAH-box region.

\section{Functional aspects of DDX15 and the interaction between La and DDX15}

Both the localization of endogenous DDX15 to nuclear speckles and the coprecipitation of spliceosomal $U$ RNAs from a HeLa cell extract suggest that DDX15 might play a role in pre-mRNA splicing. This hypothesis is in agreement with the observations that the yeast ortholog of DDX15, Prp43, is involved in a late step in pre-mRNA splicing, namely spliceosome disassembly (Arenas \& Abelson, 1997; Martin et al., 2002). Also the murine ortholog, mDEAH9, contains a similar activity, as it could functionally replace Prp43 in yeast (Gee et al., 1997). DDX15 represents the first example of a human DEAH-box protein that localizes to both nuclear speckles and nucleoli in mammalian cells. This suggests that besides a function in pre-mRNA splicing, DDX15 also plays a role in other processes. In yeast, several DEAH-box proteins, including Dhr1p and Dhr2p, localized to nucleoli, where they function in pre-rRNA processing (Colley et al., 2000). In analogy, the nucleolar pool of DDX15 might function in pre-rRNA processing. What then could be the functional relevance of the DDX15-La interaction? In yeast, the La ortholog, Lhp1p, has been shown to be involved in the biogenesis of the U1, U2, U4, U5, and U6 snRNPs (Pannone et al., 1998; Kufel et al., 2000; Xue et al., 2000). La is the first protein to bind to newly transcribed RNA polymerase III transcripts, including U6 snRNA. A fraction of the La protein molecules is known to reside in the nucleolus (Pruijn et al., 1997; Maraia \& Intine, 2002), and several RNA polymerase III transcripts like U6 snRNA (Lange \& Gerbi, 2000), pre-tRNAs (Bertrand et al., 1998), SRP RNA (Jacobson \& Pederson, 1998; Grosshans et al., 2001), 5S rRNA (Michael \& Dreyfuss, 1996), RNAse $P$
(Jarrous et al., 1999), and RNAse MRP RNA (Jacobson et al., 1995) are (transiently) localized to this compartment as well. Therefore it has been suggested that La accompanies these RNAs to the nucleolus (Maraia, 2001). We observed a (partial) colocalization of DDX15 and La in the nucleoli. Moreover, our results suggest that there is only a low level of association between $\mathrm{La}$ and DDX15 indicating that only part of the La molecules associate with DDX15. It is possible that this interaction only occurs in the nucleoli or in another nuclear subcompartment, where the action of both proteins is required in concert. It is tempting to speculate that La recruits DDX15 to the RNAs mentioned above in the nucleolus, where DDX15 might be required for further processing of these RNAs and for their assembly into RNPs. Proof for such a concerted action of La and DDX15 might be provided by yeast strains lacking both Lhp1p and the yeast DDX15 protein, Prp43.

\section{MATERIALS AND METHODS}

\section{Sera and antibodies}

Monoclonal antibodies 2G10 (anti-Ro60; Veldhoven et al., 1995), SW5 (anti-La; Pruijn et al., 1995), 4G3 (anti-U2B"; Habets et al., 1989), 72B9 (anti-fibrillarin; Reimer et al., 1987), and Y12 (anti-Sm; Lerner et al., 1981) have been described before. Anti-VSV-G-tag antibody was purchased from Roche Diagnostics (Almere, The Netherlands). Rabbit serum against human Prp43/DDX15 was a kind gift of Dr. C.L. Will (Max Planck Institute for Biophysical Chemistry, Göttingen, Germany). Peroxidase-conjugated, Texas Red-conjugated, and FITC-conjugated secondary antibodies were from Dako Immunoglobulins (Glostrup, Denmark).

\section{Cell extracts}

S100 extracts were prepared from HeLa cells purchased from Computer Cell Culture Center (Mons, Belgium). Briefly, cells were washed twice in isotonic buffer $(10 \mathrm{mM}$ Tris- $\mathrm{HCl}, \mathrm{pH} 7.9$, $140 \mathrm{mM} \mathrm{KCl}, 1.5 \mathrm{mM} \mathrm{MgCl}_{2}$, 1 mM EDTA, $1 \mathrm{mM}$ DTE, 20\% glycerol), resuspended in 2 vol of buffer A (25 mM Tris- $\mathrm{HCl}$, $\mathrm{pH} 7.4,50 \mathrm{mM} \mathrm{KCl}, 1.5 \mathrm{mM} \mathrm{MgCl}$, 1 mM EDTA, 1 mM DTE, $20 \%$ glycerol) and disrupted by dounce homogenization. Nuclei were removed by centrifugation $(3,000 \times g, 5 \mathrm{~min})$ and the supernatant was first centrifuged for $20 \mathrm{~min}$ at $20,000 \times$ $g$, followed by centrifugation at $100,000 \times g$ for $1 \mathrm{~h}$.

Extracts from HeLa cells were prepared after harvesting $(800 \times g, 5 \mathrm{~min})$ and washing of the cells with ice-cold PBS. Cells were lysed in lysis buffer $(25 \mathrm{mM}$ Tris- $\mathrm{HCl}, \mathrm{pH} 7.5$, $100 \mathrm{mM} \mathrm{KCl}, 1 \mathrm{mM}$ DTE, 2 mM EDTA, $0.5 \mathrm{mM}$ PMSF, $1 \%$ $\mathrm{NP}-40)$. After $15 \mathrm{~min}$, insoluble material was removed by centrifugation $(16,000 \times g, 15 \mathrm{~min})$ and the extract was stored at $-70^{\circ} \mathrm{C}$.

\section{Isolation of proteins coprecipitating with SW5}

Protein A-agarose beads were coated with SW5 using a rabbit anti-mouse bridge, or rabbit anti-mouse alone as a 
control antibody, by overnight end-over-end rotation at $4{ }^{\circ} \mathrm{C}$ in $\mathrm{IPP}_{500}(10 \mathrm{mM}$ Tris- $\mathrm{HCl}, \mathrm{pH} 8.0,500 \mathrm{mM} \mathrm{NaCl}, 0.05 \%$ NP-40). HeLa S100 extract (from $1 \times 10^{9}$ cells) was diluted in $\mathrm{IPP}_{100}(10 \mathrm{mM}$ Tris- $\mathrm{HCl}, \mathrm{pH} 8.0,100 \mathrm{mM} \mathrm{NaCl}$, $0.05 \% \mathrm{NP}-40$ ) and incubated with SW5-, or rabbit-antimouse-coated protein A-agarose beads for $2 \mathrm{~h}$ at $4^{\circ} \mathrm{C}$. After extensive washing with $\mathrm{IPP}_{100}$, proteins were eluted in $\mathrm{IPP}_{1000}(10 \mathrm{mM}$ Tris- $\mathrm{HCl}, \mathrm{pH} 8.0,1,000 \mathrm{mM} \mathrm{NaCl}, 0.05 \%$ NP-40; $30 \mathrm{~min}, 4^{\circ} \mathrm{C}$ ), followed by acetone precipitation and solubilization in SDS sample buffer. Proteins were resolved by $12 \%$ SDS-PAGE and stained with Coomassie Brilliant Blue. Bands of interest were excised, destained, and subsequently digested with trypsin and processed for Q-TOFmass spectrometry according to Raymackers et al. (2000). Peptide sequences obtained by mass spectrometry were used to identify the coprecipitated proteins using the NCBI nonredundant protein database.

\section{Immunoprecipitation}

Protein A-agarose beads were coated with 2G10, SW5, Y12, anti-hPrp43/DDX15 rabbit serum, or the corresponding preimmune serum, by overnight incubation at $4{ }^{\circ} \mathrm{C}$ in $\mathrm{IPP}_{500}$. Subsequently, the antibody-coated beads were incubated with either HeLa S100 extracts or total HeLa extracts (for RNA isolation) in $\mathrm{IPP}_{150}$ for $2 \mathrm{~h}$ at $4{ }^{\circ} \mathrm{C}$. Then the beads were extensively washed with $\mathrm{IPP}_{150}$, and the coprecipitating RNAs were isolated by phenol/chloroform extraction and ethanol precipitation. The coprecipitated RNAs were separated by denaturing polyacrylamide gel electrophoresis and visualized by silver staining according to the protocol by Blum et al. (1987). Alternatively, coprecipitated proteins were solubilized in SDS sample buffer or two-dimensional sample buffer (for 2D-IEF/SDS-PAGE analysis) and processed for immunoblotting. Two-dimensional-IEF/SDS-PAGE was done according to protocols described by Broekhuis et al. (2000).

\section{Immunoblotting}

Western blots containing HeLa S100 extracts or immunoprecipitated proteins were prepared, blocked in wash buffer $(5 \%$ nonfat dried milk, $0.1 \%$ NP-40, PBS) for $1 \mathrm{~h}$ at room temperature, and incubated with antibodies against DDX15 (antihPrp43/DDX15; 1:500), for $1 \mathrm{~h}$ at room temperature. After washing, filters were incubated with HRP-conjugated secondary antibodies and bound antibodies were visualized by chemiluminescence.

\section{Constructs and recombinant protein expression}

For in vitro transcription/translation and transfection analyses, an N-terminally VSV-G-tagged DDX15 protein construct was generated. The N-terminal VSV-G-tag (MEIYTDIEMNR LGK) was introduced via PCR using the following primers: DDX15-1 (5'-GCGAATTCGCCACCATGGAGATTTATACAG ACATAGAGATGAACCGACTTGGAAAGCGCGGCCGCAT GTCCAAGCGGCACCGGTTG-3') and DDX15-2 (5' -GCCTC GAGTCAGTACTGTGAATATTCCTTGGATTG-3') using DNA from a human placental cDNA library as template. Indicated in bold are the introduced EcoRI, Notl, and Xhol sites, re- spectively. The VSV-G-tag encoding sequence is underlined. The PCR product was digested with EcoRI/Xhol and cloned in the corresponding sites of the pcDNA3 vector (Invitrogen). Deletion mutants of DDX15 were generated using a PCRbased approach by amplifying the desired regions of DDX15 using gene-specific primers and the full-length DDX15 cDNA as template. The following mutants were made: $\Delta$ N63 (amino acids 63 to 795 ), $\Delta \mathrm{N} 153$ (amino acids 153 to 795 ), $\Delta \mathrm{N} 286$ (amino acids 286 to 795), $\Delta \mathrm{C} 689$ (amino acids 1 to 689 ), $\Delta$ C583 (amino acids 1 to 583), $\Delta$ C477 (amino acids 1 to 477 ), 63-477 (amino acids 63 to 477), and 153-477 (amino acids 153 to 477). The integrity of all constructs was confirmed by DNA sequencing. Constructs for the in vitro translation of human hnRNP I and hnRNP K have been described (Fabini et al., 2001). A GST-La fusion-protein construct was generated by inserting the full-length human La cDNA (Pruijn, 1994) in-frame to a GST-encoding sequence from the pGEX-4 vector (Pharmacia, Roosendaal, The Netherlands). GST-La and GST were expressed and purified according to protocols supplied by the manufacturer (Pharmacia).

\section{Transfection and indirect immunofluorescence of HEp-2 cells}

HEp-2 cells were grown in Dulbecco's modified Eagle's medium containing $10 \%$ heat-inactivated fetal calf serum and penicillin and streptomycin at $37^{\circ} \mathrm{C}$ in the presence of $5 \%$ $\mathrm{CO}_{2}$. Logarithmically growing HEp-2 cells were transfected with the VSV-G-tagged DDX15 protein transfection plasmids by means of electroporation. Per transfection, $5 \times 10^{6}$ cells were electroporated with $10 \mu \mathrm{g}$ of plasmid DNA in $0.8 \mathrm{~mL}$ of medium at $276 \mathrm{~V}$ and a capacity of $950 \mu \mathrm{F}$ using a Gene Pulser II (BioRad). After transfection, cells were resuspended in $10 \mathrm{~mL}$ of culture medium and grown on coverslips for $24 \mathrm{~h}$. Subsequently, the HEp-2 cells were fixed in 100\% methanol $\left(-20^{\circ} \mathrm{C}, 5 \mathrm{~min}\right)$, rehydrated in PBS, and incubated with antiVSV-G-tag antibody diluted 1:1,000 in PBS. Cells were washed three times in PBS and incubated with FITC-conjugated rabbit anti-mouse immunoglobulins.

\section{Colocalization experiments}

For colocalization experiments, HEp-2 cells grown on coverslips were fixed and incubated with anti-hPrp43/DDX15 rabbit serum (diluted 1:100 in PBS), followed by washing and incubation with secondary FITC-conjugated swine anti-rabbit antibody. Subsequently, the cells were incubated with either anti-La (mAb SW5), anti-Sm (mAb Y12), or anti-U2B" (mAb 4G3), or anti-fibrillarin (mAb 72B9) diluted 1:10 in PBS, followed by washing and incubation with Texas Red-conjugated sheep anti-mouse antibody. The cells were analyzed by confocal fluorescence microscopy.

\section{In vitro translation and immunoprecipitation}

In vitro-translated ${ }^{35}$ S-methionine labeled wild-type DDX15 protein and mutants thereof and hnRNP I and hnRNP K were synthesized using the TNT T7 Quick Coupled Reticulocyte Lysate System (Promega) as described by the manufacturer, using the VSV-G-tagged DDX15 (mutant) proteins in the pcDNA3 vector as templates. For GST pull-down experi- 
ments, glutathione beads ( $10 \mu \mathrm{L}$ of packed beads) were incubated with equimolar amounts of recombinant GST (control; $100 \mathrm{ng}$ protein) or recombinant GST-La in $\mathrm{PDB}_{300}(20 \mathrm{mM}$ HEPES, pH 7.5, $300 \mathrm{mM} \mathrm{KCl,} 5 \mathrm{mM} \mathrm{MgCl}_{2}, 0.5 \mathrm{mM}$ EDTA, $0.05 \%$ NP-40, $5 \mathrm{mM}$ DTE, $0.02 \% \mathrm{BSA}$ ) for $1 \mathrm{~h}$ at room temperature. After extensive washing with $\mathrm{PDB}_{300},{ }^{35} \mathrm{~S}$-methionine labeled DDX15 proteins were incubated with the GST- or GST-La-coated beads in PDB $_{300}$ in a total volume of $0.5 \mathrm{~mL}$ for $1 \mathrm{~h}$ at $4{ }^{\circ} \mathrm{C}$. After extensive washing, bound protein was eluted in SDS-sample buffer, separated by SDS-PAGE and visualized by autoradiography.

\section{ACKNOWLEDGMENTS}

We are grateful to J. Raymackers and Dr. L. Meheus (Innogenetics N.V., Ghent, Belgium) for mass spectrometry analyses and Dr. C.L. Will (Max Planck Institute for Biophysical Chemistry, Göttingen, Germany) for the generous gift of anti-hPrp43/ DDX15 rabbit serum and critical reading of the manuscript. We also thank Dr. J.G. Conboy (Lawrence Berkeley National Laboratory, Berkeley, California) for providing reagents in the initial phase of this study and Erik Vossenaar for help in the preparation of figures. This research has been financially supported by the Council for Chemical Sciences of the Netherlands Organization for Scientific Research (CW-NWO).

Received February 21, 2002; returned for revision

March 11, 2002; revised manuscript received

August 29, 2002

\section{REFERENCES}

Aigner S, Lingner J, Goodrich KJ, Grosshans CA, Shevchenko A, Mann M, Cech TR. 2000. Euplotes telomerase contains an La motif protein produced by apparent translational frameshifting. EMBO J 19:6230-6239.

Ali N, Pruijn GJ, Kenan DJ, Keene JD, Siddiqui A. 2000. Human La antigen is required for the hepatitis $C$ virus internal ribosome entry site-mediated translation. $J$ Biol Chem 275:27531-27540.

Ali N, Siddiqui A. 1997. The La antigen binds 5 ' noncoding region of the hepatitis $C$ virus RNA in the context of the initiator AUG codon and stimulates internal ribosome entry site-mediated translation. Proc Natl Acad Sci USA 94:2249-2254.

Andersen JS, Lyon CE, Fox AH, Leung AK, Lam YW, Steen H, Mann M, Lamond Al. 2002. Directed proteomic analysis of the human nucleolus. Curr Biol 12:1-11.

Arenas JE, Abelson JN. 1997. Prp43: An RNA helicase-like factor involved in spliceosome disassembly. Proc Natl Acad Sci USA 94:11798-11802.

Aris JP, Blobel G. 1991. cDNA cloning and sequencing of human fibrillarin, a conserved nucleolar protein recognized by autoimmune antisera. Proc Natl Acad Sci USA 88:931-935.

Bachmann M, Pfeifer K, Schroder HC, Muller WE. 1990. Characterization of the autoantigen La as a nucleic acid-dependent ATPase/ dATPase with melting properties. Cell 60:85-93.

Bai C, Li Z, Tolias PP. 1994. Developmental characterization of a Drosophila RNA-binding protein homologous to the human systemic lupus erythematosus-associated La/SS-B autoantigen. Mol Cell Biol 14:5123-5129.

Bertrand E, Houser-Scott F, Kendall A, Singer RH, Engelke DR. 1998. Nucleolar localization of early tRNA processing. Genes \& Dev 12:2463-2468.

Blum H, Beier H, Gross HJ. 1987. Improved silver staining of plant proteins, RNA and DNA in polyacrylamide gels. Electrophoresis 8:93-105.

Broekhuis CH, Neubauer G, Van der Heijden A, Mann M, Proud CG, Van Venrooij WJ, Pruijn GJ. 2000. Detailed analysis of the phos- phorylation of the human La (SS-B) autoantigen. (De)phosphorylation does not affect its subcellular distribution. Biochemistry 39:3023-3033.

Colley A, Beggs JD, Tollervey D, Lafontaine DL. 2000. Dhr1p, a putative DEAH-box RNA helicase, is associated with the box C+D snoRNP U3. Mol Cell Biol 20:7238-7246.

De la Cruz J, Kressler D, Linder P. 1999. Unwinding RNA in Saccharomyces cerevisiae: DEAD-box proteins and related families. Trends Biochem Sci 24:192-198.

Fabini G, Raijmakers R, Hayer S, Fouraux MA, Pruijn G, Steiner G. 2001. The heterogeneous nuclear ribonucleoproteins I and $\mathrm{K}$ interact with a subset of the Ro ribonucleoprotein-associated Y RNAs in vitro and in vivo. $\mathrm{J} \mathrm{Biol}$ Chem 276:20711-20718.

Fan $\mathrm{H}$, Goodier JL, Chamberlain JR, Engelke DR, Maraia RJ. 1998. $5^{\prime}$ processing of tRNA precursors can be modulated by the human La antigen phosphoprotein. Mol Cell Biol 18: 3201-3211.

Ford LP, Shay JW, Wright WE. 2001. The La antigen associates with the human telomerase ribonucleoprotein and influences telomere length in vivo. RNA 7:1068-1075.

Fouraux MA, Bouvet P, Verkaart S, Van Venrooij WJ, Pruijn GJM. 2002a. Nucleolin associates with a subset of the human Ro ribonucleoprotein complexes. J Mol Biol 320:475-488.

Fouraux MA, Van der Heijden A, Van Venrooij WJ, Pruijn GJM. 2002b. Cross-reactivity of the anti-La monoclonal antibody SW5 with early endosome antigen 2. Immunology 106:336-342.

Francoeur AM, Mathews MB. 1982. Interaction between VA RNA and the lupus antigen La: Formation of a ribonucleoprotein particle in vitro. Proc Natl Acad Sci USA 79:6772-6776.

Gee S, Krauss SW, Miller E, Aoyagi K, Arenas J, Conboy JG. 1997. Cloning of mDEAH9, a putative RNA helicase and mammalian homologue of Saccharomyces cerevisiae splicing factor Prp43. Proc Natl Acad Sci USA 94:11803-11807.

Gorbalenya AE, Koonin EV, Donchenko AP, Blinov VM. 1989. Two related superfamilies of putative helicases involved in replication, recombination, repair and expression of DNA and RNA genomes. Nucleic Acids Res 17:4713-4730.

Gottlieb E, Steitz JA. 1989a. Function of the mammalian La protein: Evidence for its action in transcription termination by RNA polymerase III. EMBO J 8:851-861.

Gottlieb E, Steitz JA. 1989b. The RNA binding protein La influences both the accuracy and the efficiency of RNA polymerase III transcription in vitro. EMBO $J$ 8:841-850.

Grosshans H, Deinert K, Hurt E, Simos G. 2001. Biogenesis of the signal recognition particle (SRP) involves import of SRP proteins into the nucleolus, assembly with the SRP-RNA, and Xpo1pmediated export. J Cell Biol 153:745-762.

Habets WJ, Hoet MH, De Jong BA, Van der Kemp A, Van Venrooij WJ. 1989. Mapping of B cell epitopes on small nuclear ribonucleoproteins that react with human autoantibodies as well as with experimentally-induced mouse monoclonal antibodies. $J \mathrm{Im}$ munol 143:2560-2566.

Hendrick JP, Wolin SL, Rinke J, Lerner MR, Steitz JA. 1981. Ro small cytoplasmic ribonucleoproteins are a subclass of La ribonucleoproteins: Further characterization of the Ro and La small ribonucleoproteins from uninfected mammalian cells. Mol Cell Biol 1:1138-1149.

Huhn P, Pruijn GJ, Van Venrooij WJ, Bachmann M. 1997. Characterization of the autoantigen La (SS-B) as a dsRNA unwinding enzyme. Nucleic Acids Res 25:410-416.

Imamura O, Sugawara M, Furuichi Y. 1997. Cloning and characterization of a putative human RNA helicase gene of the DEAH-box protein family. Biochem Biophys Res Commun 240:335-340.

Jacobson MR, Cao LG, Wang YL, Pederson T. 1995. Dynamic localization of RNase MRP RNA in the nucleolus observed by fluorescent RNA cytochemistry in living cells. J Cell Biol 131: 1649-1658.

Jacobson MR, Pederson T. 1998. Localization of signal recognition particle RNA in the nucleolus of mammalian cells. Proc Natl Acad Sci USA 95:7981-7986.

James MC, Jeffrey IW, Pruijn GJ, Thijssen JP, Clemens MJ. 1999. Translational control by the La antigen. Structure requirements for rescue of the double-stranded RNA-mediated inhibition of protein synthesis. Eur J Biochem 266:151-162.

Jankowsky E, Gross CH, Shuman S, Pyle AM. 2001. Active disrup- 
tion of an RNA-protein interaction by a DExH/D RNA helicase. Science 291:121-125.

Jarrous N, Wolenski JS, Wesolowski D, Lee C, Altman S. 1999. Localization in the nucleolus and coiled bodies of protein subunits of the ribonucleoprotein ribonuclease P. J Cell Biol 146:559-572.

Kufel J, Allmang C, Chanfreau G, Petfalski E, Lafontaine DL, Tollervey D. 2000. Precursors to the U3 small nucleolar RNA lack small nucleolar RNP proteins but are stabilized by La binding. Mol Cell Biol 20:5415-5424.

Kurilla MG, Keene JD. 1983. The leader RNA of vesicular stomatitis virus is bound by a cellular protein reactive with anti-La lupus antibodies. Cell 34:837-845.

Lange TS, Gerbi SA. 2000. Transient nucleolar localization of U6 small nuclear RNA in Xenopus laevis oocytes. Mol Biol Cell 11:2419-2428.

Lerner EA, Lerner MR, Janeway CA, Steitz JA. 1981. Monoclonal antibodies to nucleic acid-containing cellular constituents: Probes for molecular biology and autoimmune disease. Proc Natl Acad Sci USA 78:2737-2741.

Linder P, Lasko PF, Ashburner M, Leroy P, Nielsen PJ, Nishi K, Schnier J, Slonimski PP. 1989. Birth of the D-E-A-D box. Nature 337:121-122.

Linder P, Tanner NK, Banroques J. 2001. From RNA helicases to RNPases. Trends Biochem Sci 26:339-341.

Maraia RJ. 1996. Transcription termination factor $\mathrm{La}$ is also an initiation factor for RNA polymerase III. Proc Natl Acad Sci USA 93:3383-3387.

Maraia RJ. 2001. La protein and the trafficking of nascent RNA polymerase III transcripts. J Cell Biol 153:F13-F18.

Maraia RJ, Intine RVA. 2001. Recognition of nascent RNA by the human La antigen: Conserved and divergent features of structure and function. Mol Cell Biol 21:367-379.

Maraia RJ, Intine RV. 2002. La protein and its associated small nuclear and nucleolar precursor RNAs. Gene Expr 10:41-57.

Martin A, Schneider S, Schwer B. 2002. Prp43 is an essential RNAdependent ATPase required for release of lariat-intron from the spliceosome. J Biol Chem 277:17743-17750.

Meerovitch K, Svitkin YV, Lee HS, Lejbkowicz F, Kenan DJ, Chan EK, Agol VI, Keene JD, Sonenberg N. 1993. La autoantigen enhances and corrects aberrant translation of poliovirus RNA in reticulocyte lysate. J Virol 67:3798-3807.

Michael WM, Dreyfuss G. 1996. Distinct domains in ribosomal protein L5 mediate $5 \mathrm{~S}$ rRNA binding and nucleolar localization. $J$ Biol Chem 271:11571-11574.

Moore MJ, Query CC, Sharp PA. 1993. Splicing of precursors to messenger RNAs by the spliceosome. In: Gesteland RF, Atkins JF, eds. The RNA world. Cold Spring Harbor, New York: Cold Spring Harbor Laboratory Press. pp 303-357.

Nicol SM, Causevic M, Prescott AR, Fuller-Pace FV. 2000. The nuclear DEAD box RNA helicase p68 interacts with the nucleolar protein fibrillarin and colocalizes specifically in nascent nucleoli during telophase. Exp Cell Res 257:272-280.

Ohno M, Shimura Y. 1996. A human RNA helicase-like protein, HRH1, facilitates nuclear export of spliced mRNA by releasing the RNA from the spliceosome. Genes \& Dev 10:997-1007.

Ortlepp D, Laggerbauer B, Mullner S, Achsel T, Kirschbaum B, Lührmann R. 1998. The mammalian homologue of Prp16p is overexpressed in a cell line tolerant to Leflunomide, a new immunoregulatory drug effective against rheumatoid arthritis. RNA 4:1007-1018.

Pannone BK, Xue D, Wolin SL. 1998. A role for the yeast La protein in U6 snRNP assembly: Evidence that the La protein is a molecular chaperone for RNA polymerase III transcripts. EMBO J 17:7442-7453.

Pruijn GJM. 1994. The La (SS-B) antigen. In: Van Venrooij WJ, Maini $\mathrm{RN}$, eds. Manual of biological markers of disease. Dordrecht: Kluwer Academic Publishers. pp B4.1/1-B4.1/14.

Pruijn GJ, Simons FH, Van Venrooij WJ. 1997. Intracellular localization and nucleocytoplasmic transport of Ro RNP components. Eur J Cell Biol 74:123-132.

Pruijn GJ, Thijssen JP, Smith PR, Williams DG, Van Venrooij WJ. 1995. Anti-La monoclonal antibodies recognizing epitopes within the RNA-binding domain of the La protein show differential capacities to immunoprecipitate RNA-associated La protein. Eur J Biochem 232:611-619.
Raymackers J, Daniels A, De Brabandere V, Missiaen C, Dauwe M, Verhaert P, Van Mechelen E, Meheus L. 2000. Identification of twodimensionally separated human cerebrospinal fluid proteins by $\mathrm{N}$-terminal sequencing, matrix-assisted laser desorption/ionizationmass spectrometry, nanoliquid chromatography-electrospray ionization-time of flight-mass spectrometry, and tandem mass spectrometry. Electrophoresis 21:2266-2283.

Reimer G, Pollard KM, Penning CA, Ochs RL, Lischwe MA, Busch H, Tan EM. 1987. Monoclonal autoantibody from a (New Zealand black $\times$ New Zealand white) F1 mouse and some human scleroderma sera target an $M_{\mathrm{r}} 34,000$ nucleolar protein of the U3 RNP particle. Arthritis Rheum 30:793-800.

Rinke J, Steitz JA. 1982. Precursor molecules of both human 5S ribosomal RNA and transfer RNAs are bound by a cellular protein reactive with anti-La lupus antibodies. Cell 29:149-159.

Rinke J, Steitz JA. 1985. Association of the lupus antigen La with a subset of U6 snRNA molecules. Nucleic Acids Res 13:2617-2629.

Scherly D, Stutz F, Lin MN, Clarkson SG. 1993. La proteins from Xenopus laevis. cDNA cloning and developmental expression. $\checkmark \mathrm{Mol}$ Biol 231:196-204.

Schmitt C, Von Kobbe C, Bachi A, Pante N, Rodrigues JP, Boscheron C, Rigaut G, Wilm M, Seraphin B, Carmo-Fonseca M, Izaurralde E. 1999. Dbp5, a DEAD-box protein required for mRNA export, is recruited to the cytoplasmic fibrils of nuclear pore complex via a conserved interaction with CAN/Nup159p. EMBO J 18:4332-4347.

Simons FH, Broers FJ, Van Venrooij WJ, Pruijn GJ. 1996. Characterization of cis-acting signals for nuclear import and retention of the La (SS-B) autoantigen. Exp Cell Res 224:224-236.

Staknis D, Reed R. 1995. Members of a family of proteins (the RD family) detected by a U1 70K monoclonal antibody are present in spliceosomal complexes. Nucleic Acids Res 23:4081-4086.

Staley JP, Guthrie C. 1998. Mechanical devices of the spliceosome: Motors, clocks, springs, and things. Cell 92:315-326.

Stefano JE. 1984. Purified lupus antigen La recognizes an oligouridylate stretch common to the $3^{\prime}$ termini of RNA polymerase III transcripts. Cell 36:145-154.

Tanner NK, Linder P. 2001. DExD/H box RNA helicases: From generic motors to specific dissociation functions. Mol Cell 8:251-262.

Thompson JD, Higgins DG, Gibson TJ. 1994. CLUSTAL W: Improving the sensitivity of progressive multiple sequence alignment through sequence weighting, position-specific gap penalties and weight matrix choice. Nucleic Acids Res 22:4673-4680.

Van Eenennaam H, Van der Heijden A, Janssen RJ, Van Venrooij WJ, Pruijn GJ. 2001. Basic domains target protein subunits of the RNase MRP complex to the nucleolus independently of complex association. Mol Biol Cell 12:3680-3689.

Van Horn DJ, Yoo CJ, Xue D, Shi H, Wolin SL. 1997. The La protein in Schizosaccharomyces pombe: A conserved yet dispensable phosphoprotein that functions in tRNA maturation. RNA 3:1434-1443.

Van Venrooij WJ, Slobbe RL, Pruijn GJ. 1993. Structure and function of La and Ro RNPs. Mol Biol Rep 18:113-119.

Veldhoven CH, Pruijn GJ, Meilof JF, Thijssen JP, Van der Kemp AW, Van Venrooij WJ, Smeenk RJ. 1995. Characterization of murine monoclonal antibodies against 60-kD Ro/SS-A and La/SS-B autoantigens. Clin Exp Immunol 101:45-54.

Wang Y, Guthrie C. 1998. PRP16, a DEAH-box RNA helicase, is recruited to the spliceosome primarily via its nonconserved $\mathrm{N}$-terminal domain. RNA 4:1216-1229.

Will CL, Lührmann R. 1997. Protein functions in pre-mRNA splicing. Curr Opin Cell Biol 9:320-328.

Xiao Q, Sharp TV, Jeffrey IW, James MC, Pruijn GJ, Van Venrooij WJ, Clemens MJ. 1994. The La antigen inhibits the activation of the interferon-inducible protein kinase PKR by sequestering and unwinding double-stranded RNA. Nucleic Acids Res 22:2512-2518.

Xue D, Rubinson DA, Pannone BK, Yoo CJ, Wolin SL. 2000. U snRNP assembly in yeast involves the La protein. EMBO J 19:1650-1660.

Yoo CJ, Wolin SL. 1994. La proteins from Drosophila melanogaster and Saccharomyces cerevisiae: A yeast homolog of the La autoantigen is dispensable for growth. Mol Cell Biol 14:5412-5424.

Yoo CJ, Wolin SL. 1997. The yeast La protein is required for the $3^{\prime}$ endonucleolytic cleavage that matures tRNA precursors. Cell 89:393-402. 